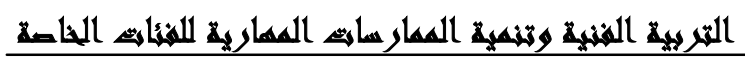

\section{خلقية البحث: - 20}

تعددت مشكلات المجتمع وتتوعت حتى بلغت مداها ،و أصبح الــدور

التربوي ضرورة لبناء الفرد .... وتحقيقاً لدور التربية الفنية فى بناء وتكوين

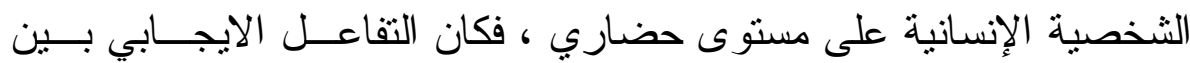

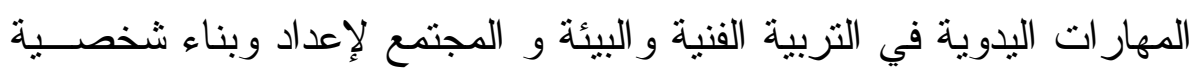
سوية إيجابية لها ارتباط وثثي بالثقافة و التزراث الفني محققة الإبداعات الفكرية المطلوبة.

وبعد أن أصبح مفهوم التربية الفنية متغيراً هاماً للتطور كان علـىى

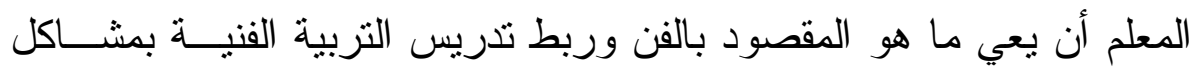

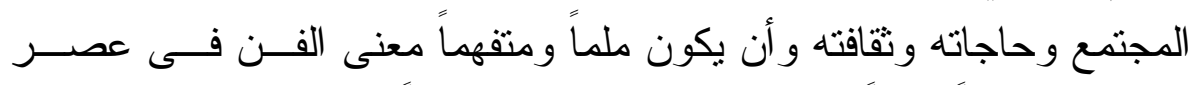

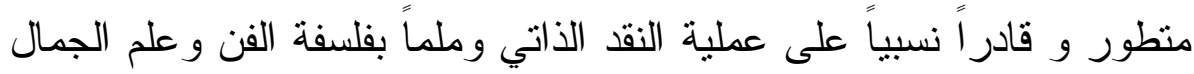

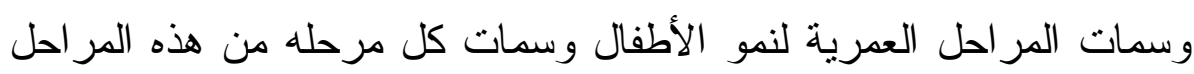
و المشكلات التى تو اجه البعض منهم ووضع الحلول لمو اجنها. و لاشك أن التربية الفنية لها دور فعال في بناء شخصية الفرد الــذي وندي

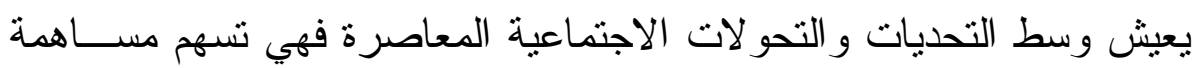
إيجابية في تتمية وصقل شخصية الطالب من النواحي العقليــة و الوجدانيـــة و الحسية و الحركية .

وتهنم مادة التربية الفنية بهذه النو احي اهنماما متو ازنــاً متســقاً دون

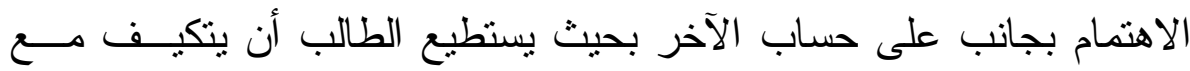

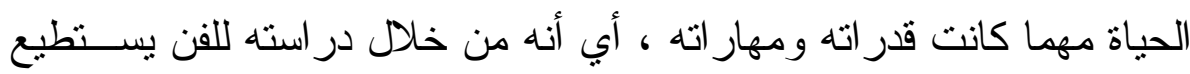
أن يضيف للحياة معنى حسب الطريقة التي يعيث بها.

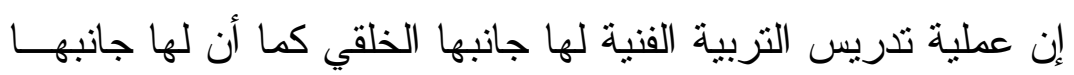
العلمي و المهني فعلى المعلم ألا يهنم بالفن كغاية في حد ذاته و أنما بشخصية الطالب أو لاً ويتخذ من الفن وسيلة لتنميتها. 
يستند تعليم الفن على منطق علمي لذلك يجــب أن نعــي العمليــات التزبوية و القيم الفنية التي نريد أن نكسبها للطالب بعد تحديد نوعيته وقدر اته

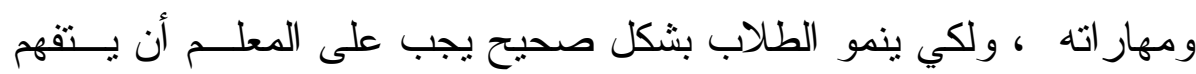
لغتهم الفنية ويفك رموزها ويستطيع أن يتقبلها بصدر رحب وينميها بصورة متكاملة تعكس عليهر عادات ابتكاريه وخلقيه و عمليه .

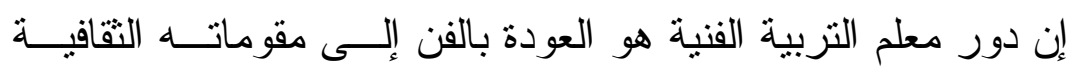
ليؤدي دوره في بناء فرد مبدع حساس مفكر يسهم بنصيب في تقدم أمتـــهـ ،

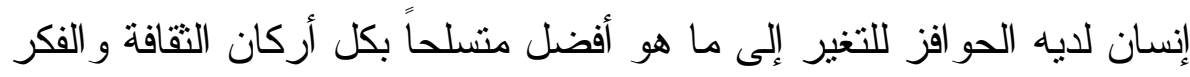

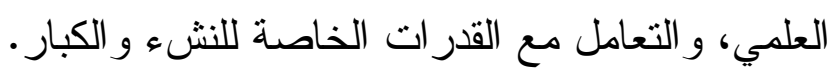
و عندما نضع الخطط الخاصة لتذريس مادة التربية الفنية للمر احـلـ العمرية المختلفة و إعداد النشه علينا أن ندرك طبيعــة العينــة المســتهدفة فئهة

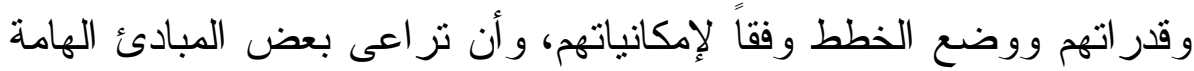
في اختيار الدروس وفق كل فئة وقدر اتهم ومهارتهم المختلفة

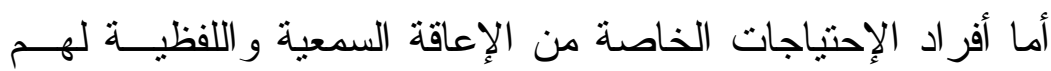
طبيعتهم المز اجية و الانفعالية ولهم إمكانياتهم المبدعة وهى نوعية من الإعاقة الإقة تستلزم وضع خطة للتدريس تلائم طبيعة هذه الفئة حتى يستمتعون بإنتـــاجهم

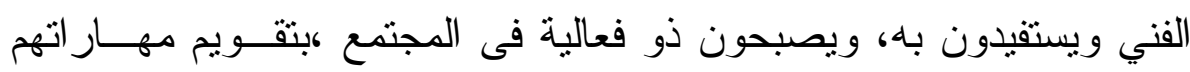

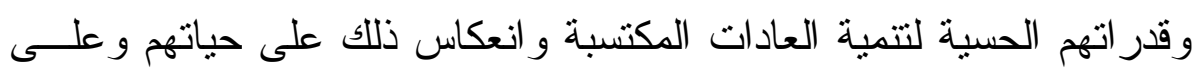

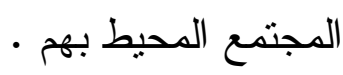
كما يأتي دور التوجيه الفني البنائي لـذذوى الإحتياجــات الخاصـــة

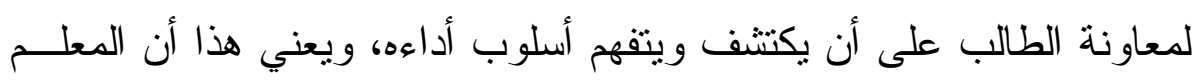

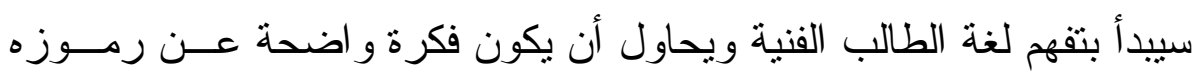

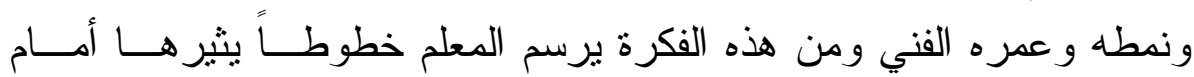
طلابه، ليساعدهم على تتمية وصقل تعبير اتهم وأن يكسب ونلابه كثير اً مـنـ 
العادات في أثناء عملية التوجيه كما يكسبهم الدقة و البحث و التفكيـر و إدر الك العلاقات التشكيلية والمرونة التي تجعل أذهانهم متفتحة قابلة للنمو و التطوير • وتنمية الممارسات المهارية للفئات الخاصة يهدف إلى: أولاً: بالنسبة للطالب:

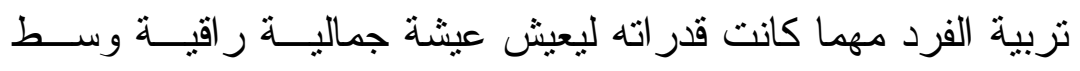

الإطار الاجتماعي المتطور أثناء ممارستهم للعمل الفني و النشاط المنهجي .

الكثف عن الطلاب الموهوبين من الاحتياجــات الخاصـــة وتتميــة

$$
\text { مو اهبهم وقدر اتهم الفنية و المهنية . }
$$

تأكيد ذاتية الطلاب و إتاحة الفرص للتعبير عن انفعالاتهم ومشاعرهم

$$
\text { وتكوين شخصيتهم السوية وسط فئات المجتمع. }
$$

• تكوين القدرة على الماحظة و الرؤية الدقيقة و النقد و التــذوق الفنـي

الهادف.

• تكوين القدرة على التفكير و التأمل في بــديع صــنـع الله وموازنـــة

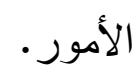

نمو الإحساس و الإدر الك الفني •

اكتساب الخبرات و المهار ات المتدرجة التي تتلائم مع أعمار الطلاب

وقدر اتهم الفردية ومستوياتهم وربطهم ببيئته ومتطلباتها و السير بالتقافة الفنية في مجالات ثر اثثا الفني و الثعبي.

احتز ام العمل اليدوي ومن يقومون به و التكيف الاجتماعي السوي.

إتاحة الفرصة للطلاب للتعبير عن أي موضوع يختارونـــه عنــدما تتكون الرغبة في نفوسهم للتعبير عنه للتنفيس عن رغباتهم ومكبوتاتهم.

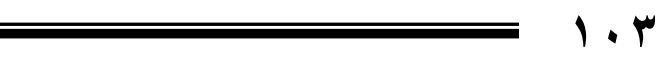




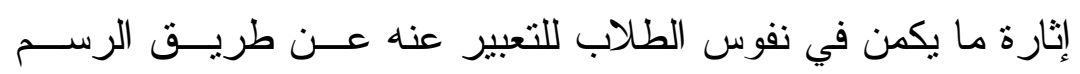

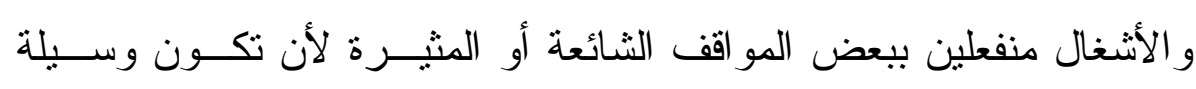
خارجية لإثارة الرغبة في التعبير و الإنتاج الفني .

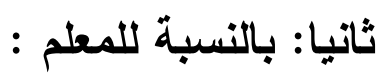

يتمثل دور معلم التربية الفنية في تهيئة المجال المحيط بالطلاب بييئة

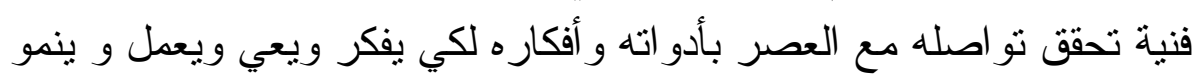

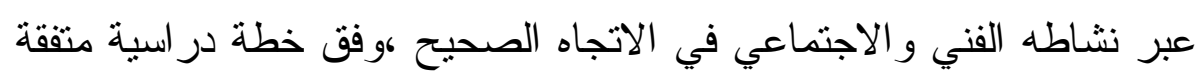

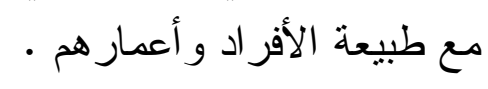
وتتلخص فى النقاط التالية:

منح المعلم الفرصة للتعرف على رغبات وقدر ات طلابه و الاســتفادة

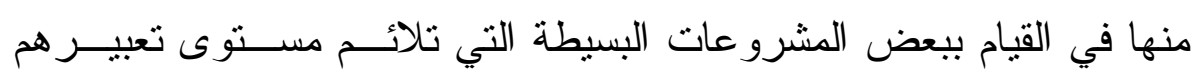

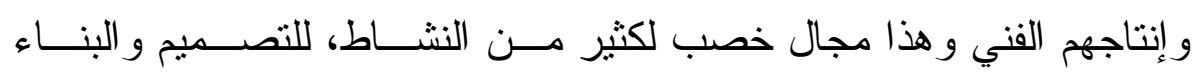

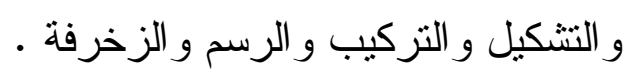

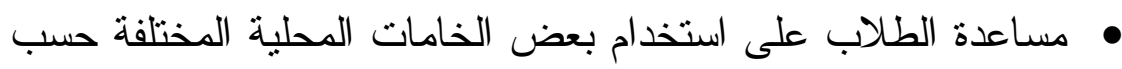

اختيار هم في التعبير عن الموضو عات تتصل بحياتهم العامة .

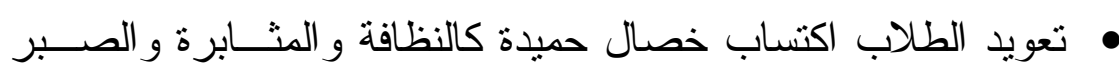
و الثقة و الملاحظة الدقيقة وتحمل المسؤولية

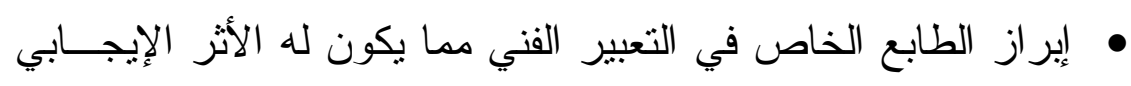
في تكامل الثخصية فالفن عملية تجديد وابتكار وليس نقلاً أو تلقيناً حرفياً.

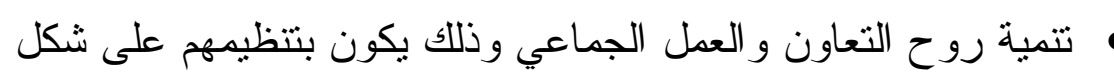

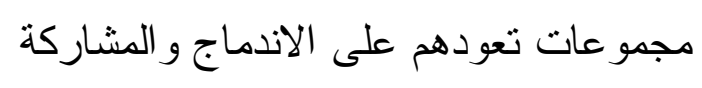

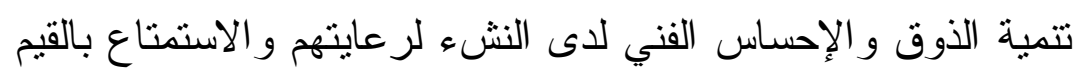

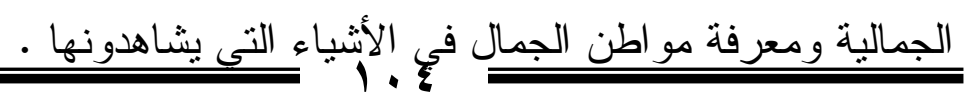




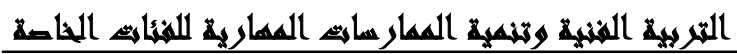

ويوضح ذللك الدور الكبير الذي يقع على عاتق معلم التربية الفنبـــة

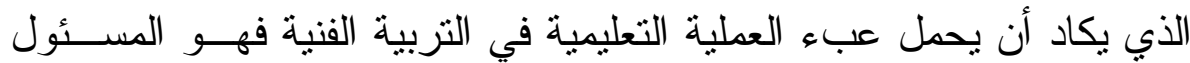

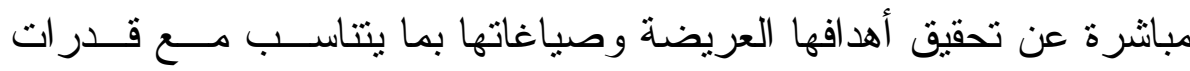

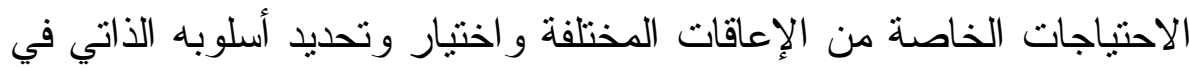

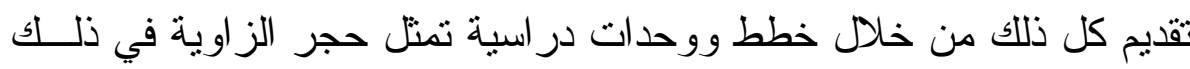

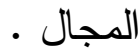

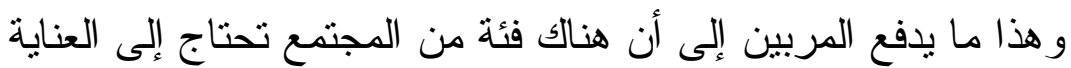

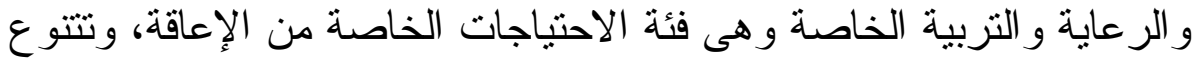

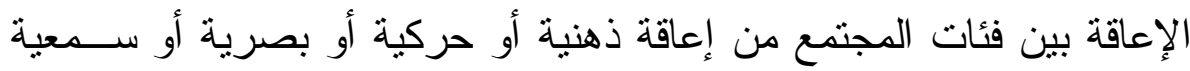

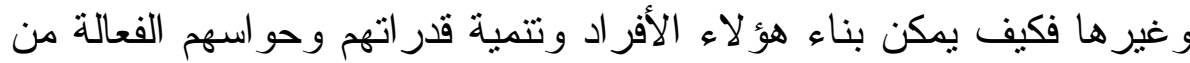

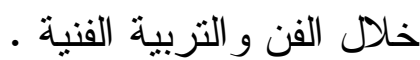

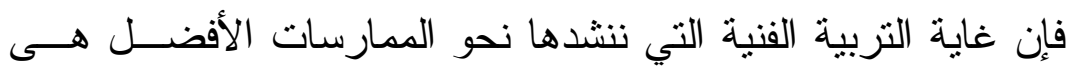

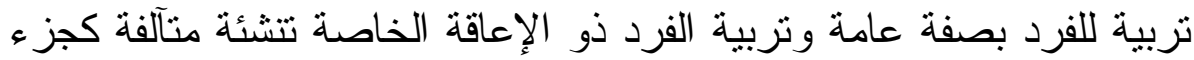

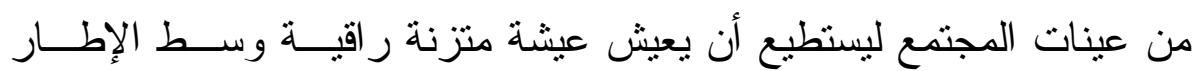

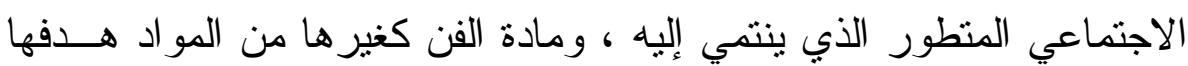

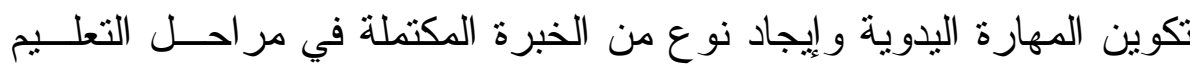
المختلفة وفق خطة مناسبة ففى السنوات الأخيرة نالت التربية الخاصة بوجه عام أهتماما بالغسـا

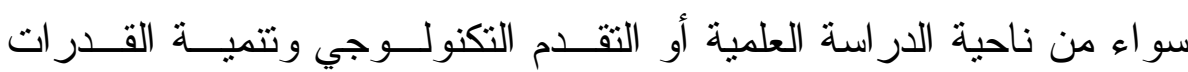

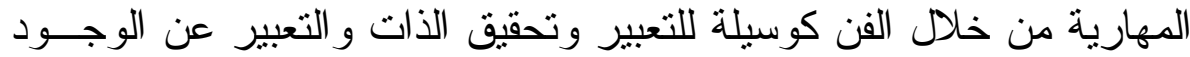

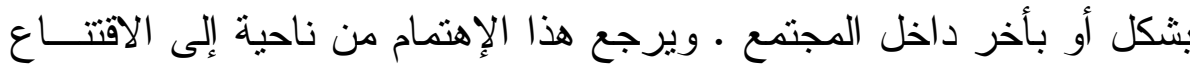

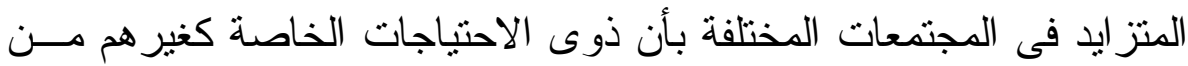

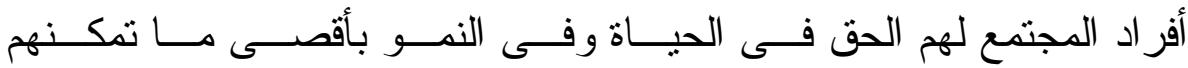
قدر اتهم ويرتبط من ناحية أخرى بتغير النظرة المجتمعية إلى هؤلاء الأفراد 


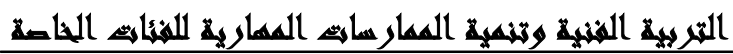

و التحول من أعتبار هم "عالة اقتصـادية" على مجتمعاتهم إلى النظـــر إلــيهرح

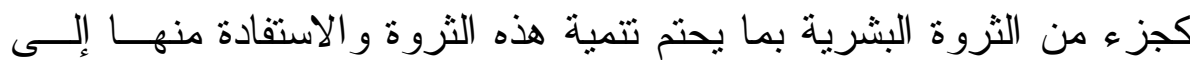

$$
\text { أقصى حد ممكن. }
$$

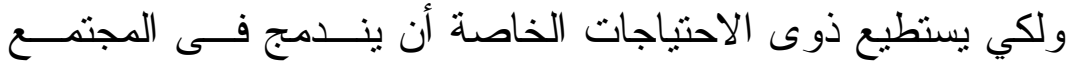

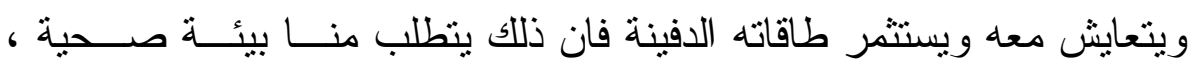

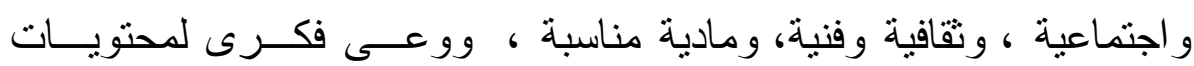

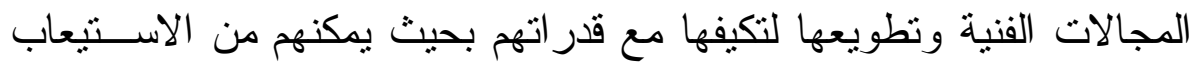

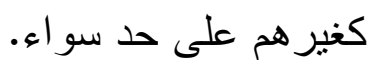

وجدير بالذكر إلى أنه في كثير من النظم التعليمية في الدول المختلفة

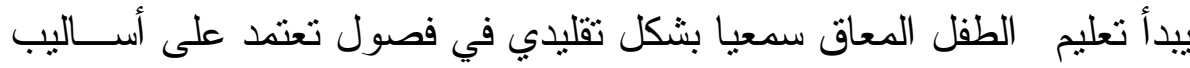

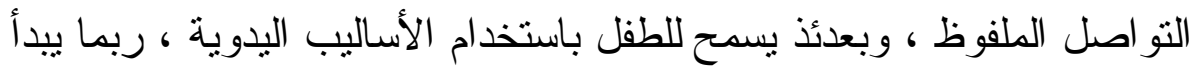

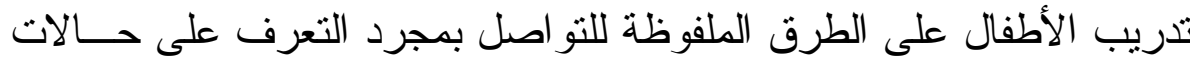

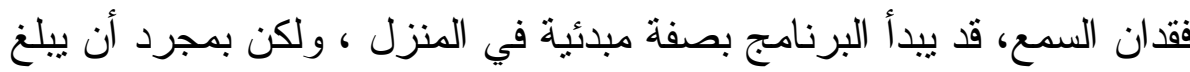

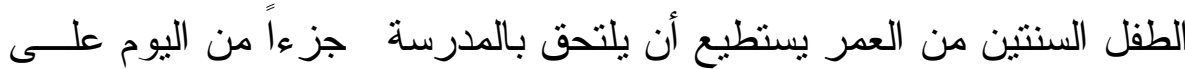

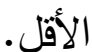

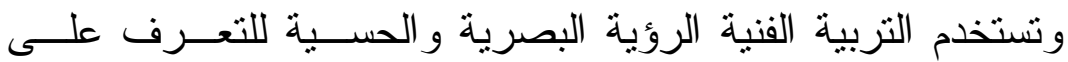

الأثتكال و الملامس و الألوان و التعبيرات المختلفــة بجانـبـ لغـــة الإثـــارة

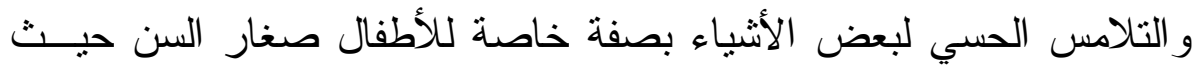

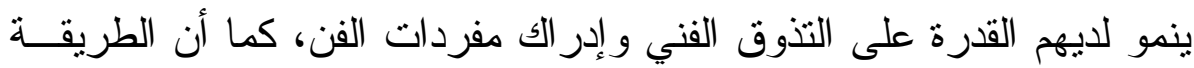

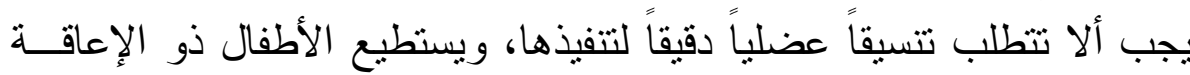

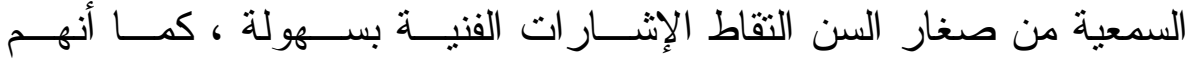

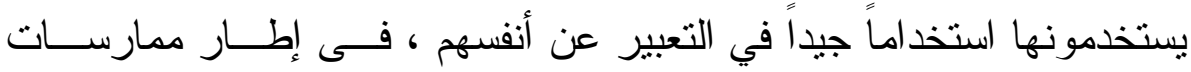

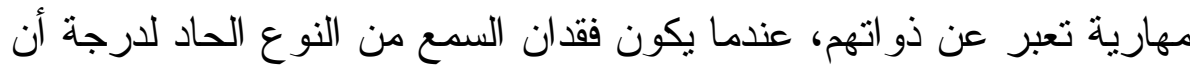

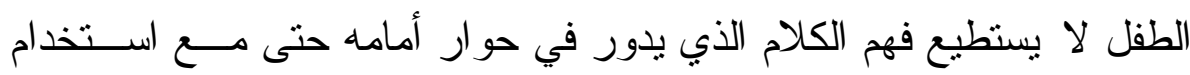




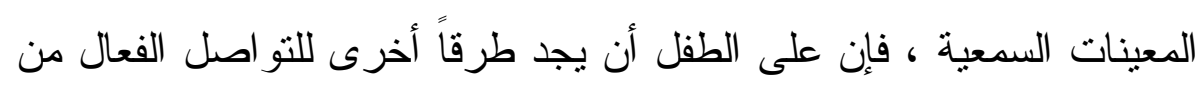
خلال التعبير بمفردات الفن المختلفة.

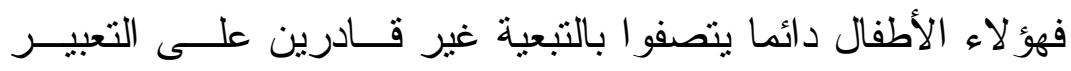

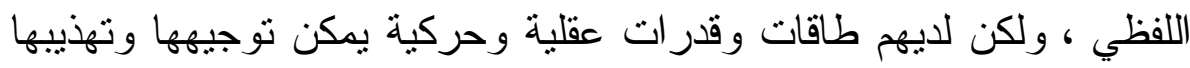

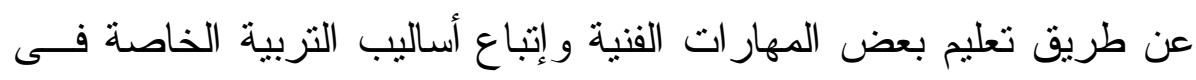
الفن وتحقيق الذات المبدعة لثخصية سوية فى مجتمع منطور . سمات الطقل المعاق سمعيا ولفظيا : فيما يلي يعرض البحث بعض سمات من شخصية الطفــل المعــاق سمعيا و التى أسهوت فى وضع مقتر ح هذا البحث :

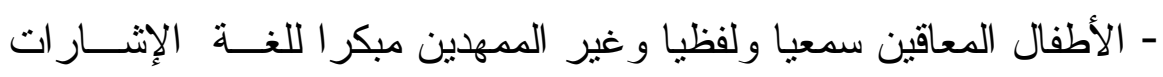

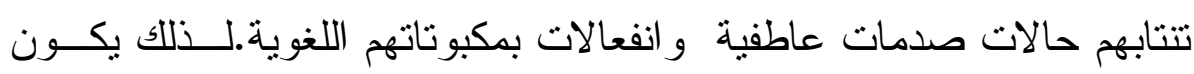

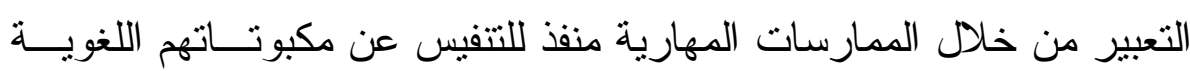
بصور مختلفة من النتكيل الفنى.

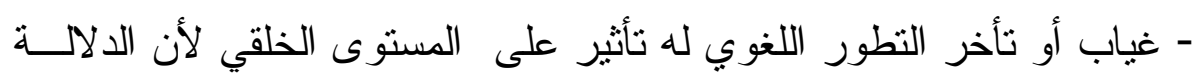

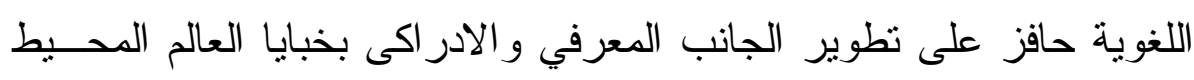

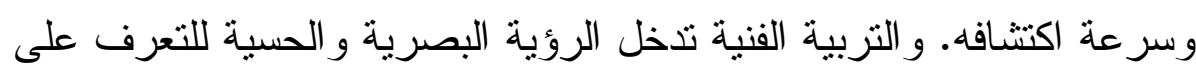
الأثكال و العناصر و القيم الفنية فى إطار معرفي وفعال. - إن الصم يشعرون بعدم استقلالية عن الأم، كما يشعرون بعدم تكيف داخل وفئل

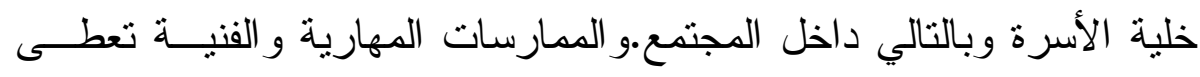
الاستقلالية و التميز و الثقة بالنفس.

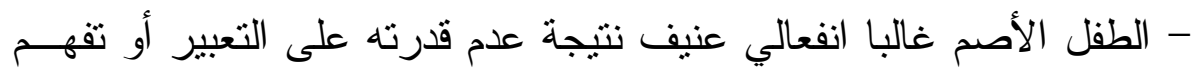

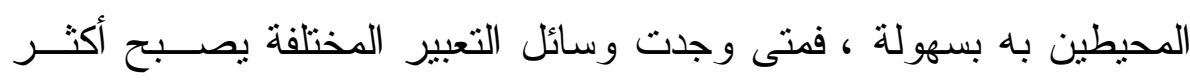

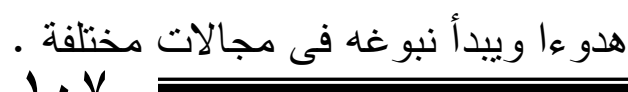




\section{التربية الفنية و الممارسات المهارية:}

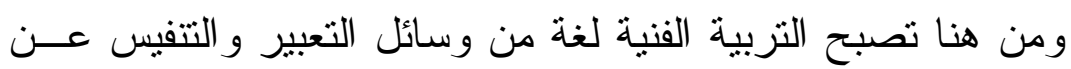

رغبات وميول هذه الفئة من خلال تدريس المجالات الفنية عامة و النسجيات

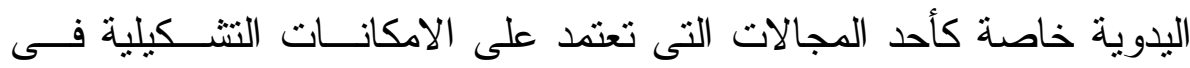

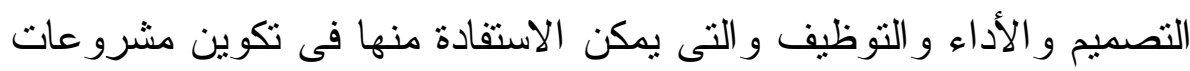

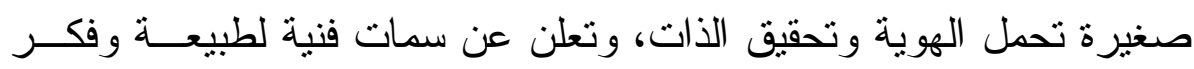

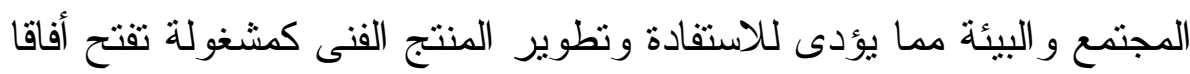

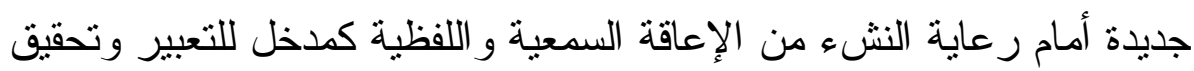
الذات و الانطلاقة الابتكارية لدى فئة قادرين على الإبداع الإعة بصور مختلفة فنيا،

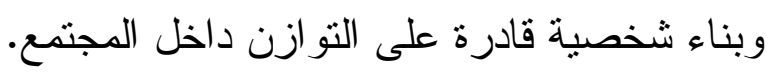

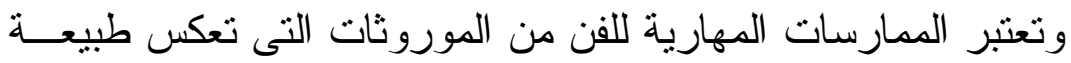

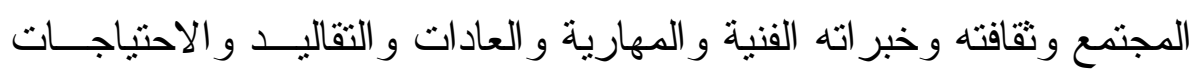

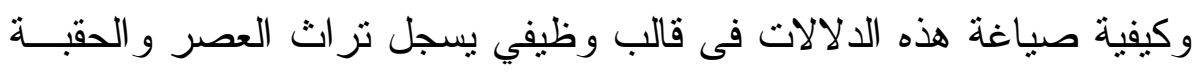

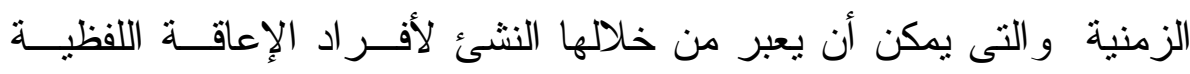

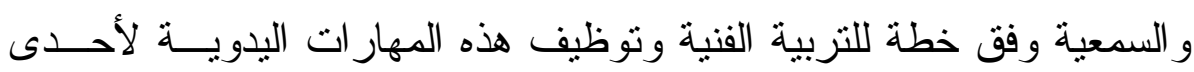

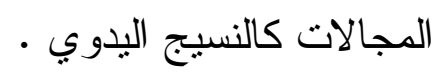

وتبعا لنطور المهار ات الفنية فى شكلها ومضمونها فى مجال الثربية

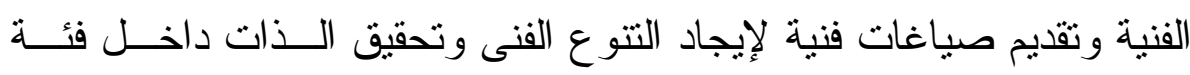

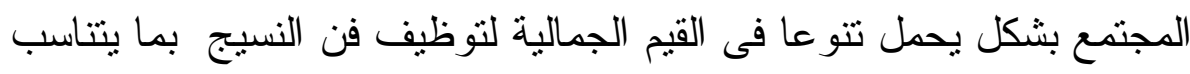

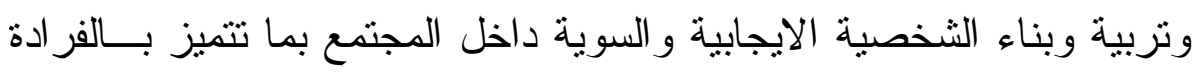

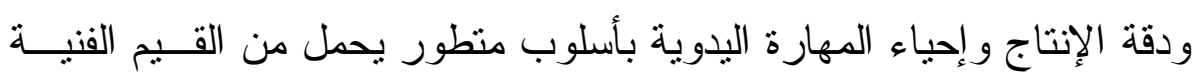

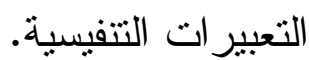




\section{النسيج اليدوى :}

يعتبر فن النسيج اليدوى فى صدارة الممارسات المهارية اليدوية التى

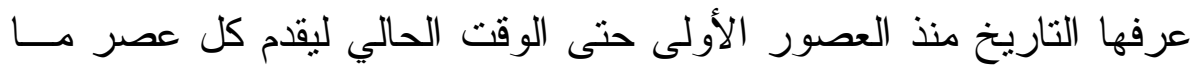
يحتاجه فى قالب وظيفي جديد.

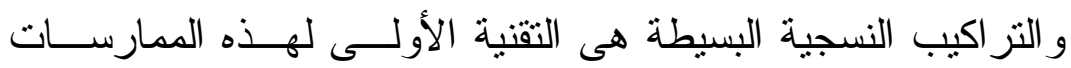

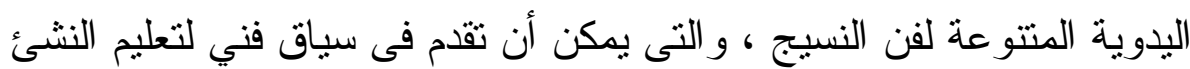

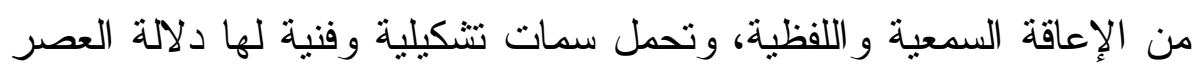

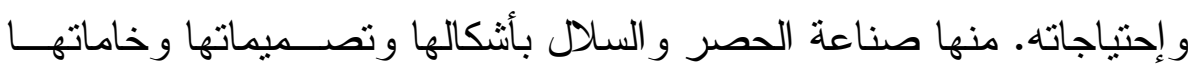
المتتوعة التى تتتاسب وتطور ات الخامة و العصر ـ وتأخذ التز اكيب النسجية

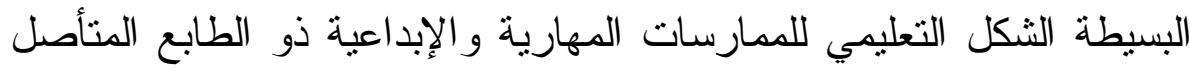

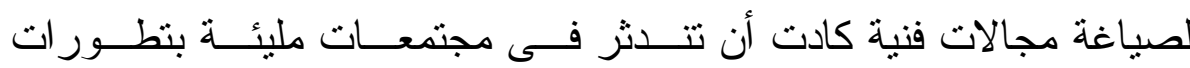

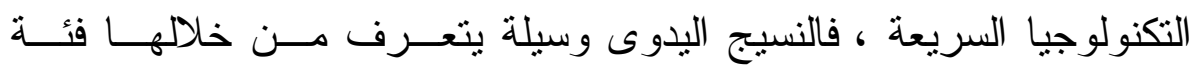

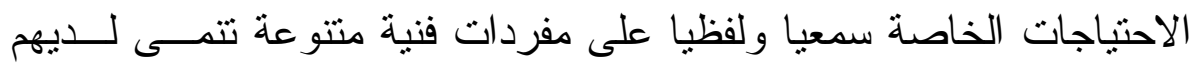
الإدر الك المعرفى لمفردات التربية الفنية من ألوان وملامس وتكوين وتركيب وليب و إبداع فى تسلسل ، ونمو يصقل الجانب المهني و الابداعى •

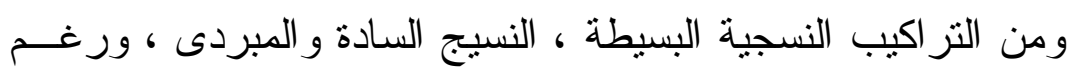

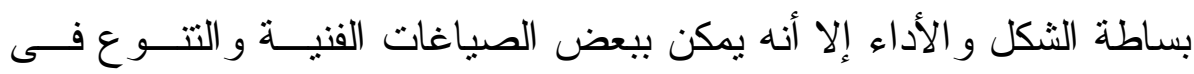

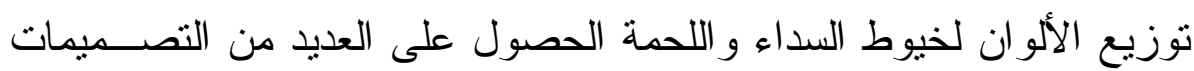

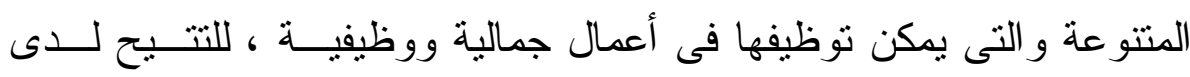
الممارس إيجاد الصياغات التشكيلية المبتكرة.

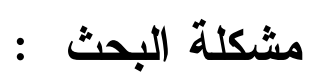
فى ضوء ما سبق تتحدد مشكلة البحث الحالي و التى يمكن صياغتها

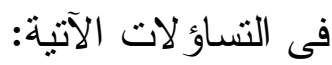


كيف يستفاد من القدرات البصرية و الحركية لأفر اد الإعاقة الســمعية

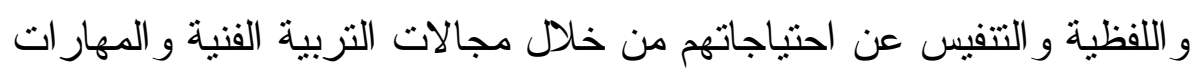

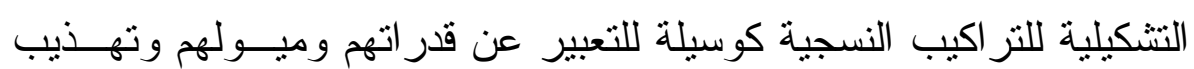
طاقاتهم المكبوتة.

• كيف نوظف المهارات النتكيلية للتر اكيب النسجية في أعمال نسجية

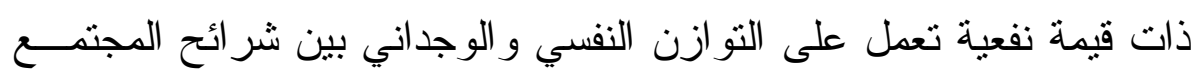
لأفر اد الإعاقة السمعية و اللفظية بشكل سوى وفعلة ولفئل

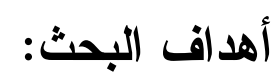
يهذف هذا البحث إلى:

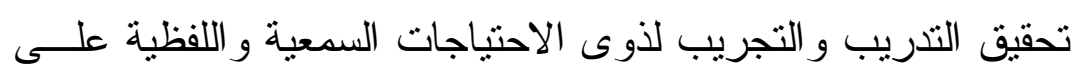

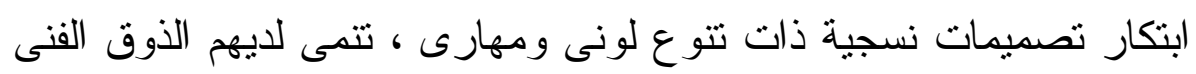
وخلق المتعة البصرية و الإدر الك المعرفي للأشكال الفنبة.

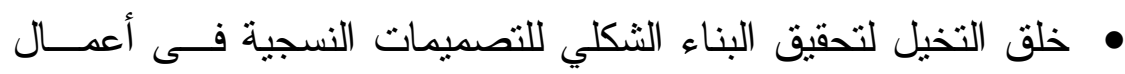

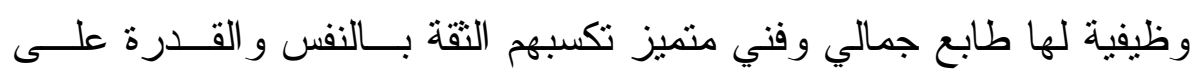
• التعبير

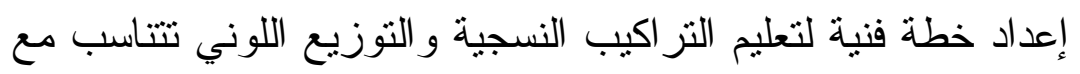

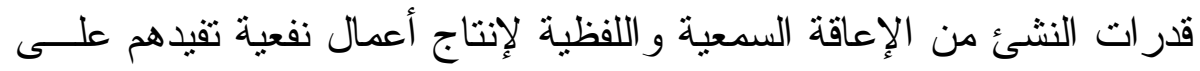

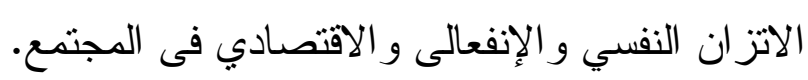

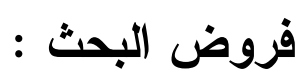

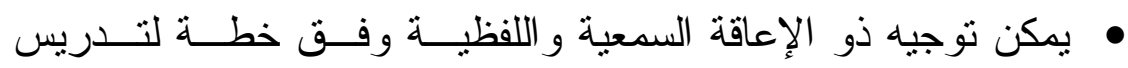

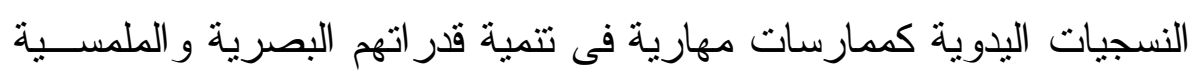

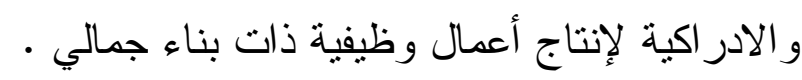




\section{حدود البحث: - (ل)}

تتحدد عينة البحث من أفر اد ذوى الاحتباجات السمعية و اللفظية .

هيتحدد مجال التربية الفنية فى توظيف الممارسات المهارية اليدويـــة

لمجال النسيج اليدوى كأحد المجالات الفنية التى يتم بها التدريب و التوجيــة للعينة البحثية.

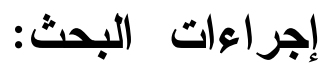

يعتمد البحث الحالي على ثناث محاور :

المحور الأول: أهمية مدرسة الباهاوس كأتجاه فني فى مجال النسيج

كمهارة بدوية . مارة

• المحور الثاني: التجريب بالثر ائط و الخيوط الملونة كمدخل لابتكــار

تصميمات زخرفية متتوعة لوحدات التشكيل الفنى المنفذة بالتر اكيب النسجية

$$
\text { البسيطة و الزخرفية. }
$$

المحور الثالث: ربط القيمة الإبداعية بالجانب الوظيفى الجمالي •

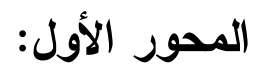

أهمية مدرسة الباوهاوس كأتجاه فني فى مجال النسيج كممارســات

مهارية يدوية : مانهاية

لقد أثز فكر مدرسة الباوهاوس Buahaus على مفهوم تدريس الفن

و أتجاهاته ، وخاصة فى مجال النسجيات اليدوية كمهار ات فنية لها مضمونها

وشكلها المميز و الاحتياج إليها فى العصر وخه الحديث.

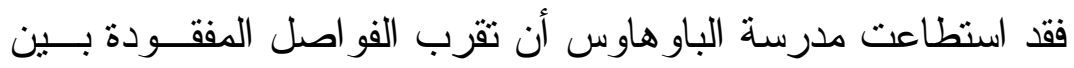

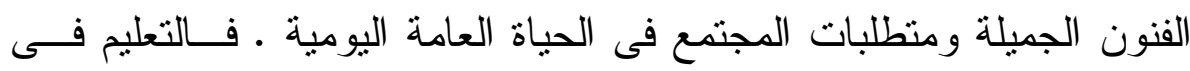

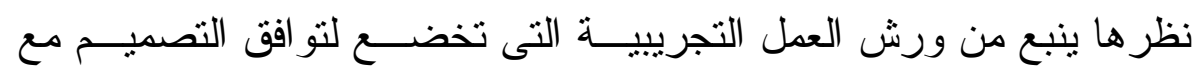




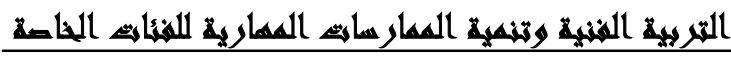

الوظيفة فأظهرت مشغو لات فنية تحقق الطابع الجمالي و الوظيفي من خلال

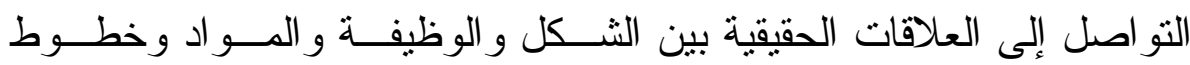

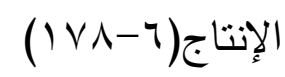

وتمارس عملية التدريس عند الباو هاوس من خال قيام الدارس بعمل

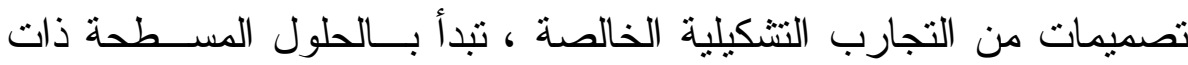

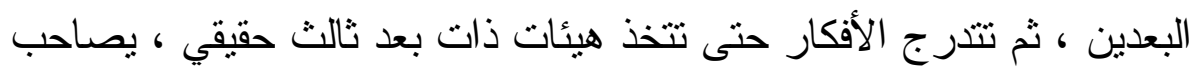

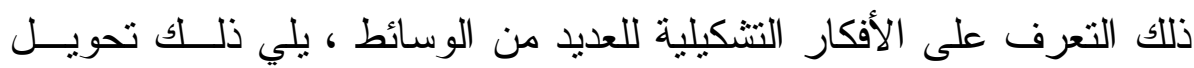

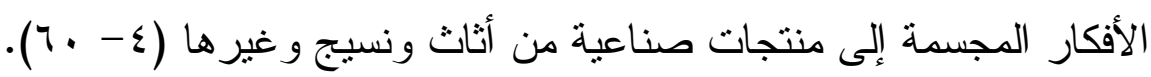

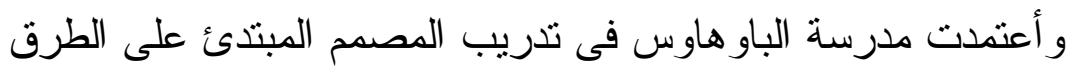

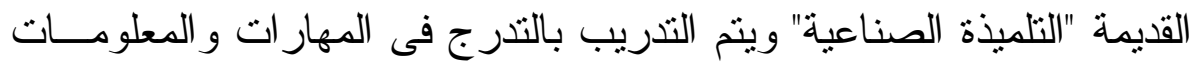

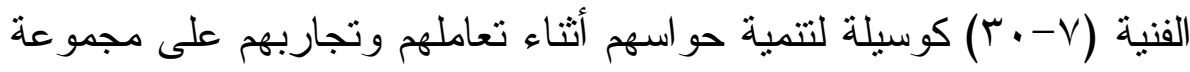

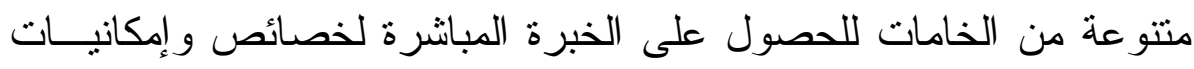

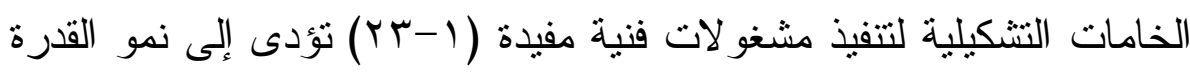

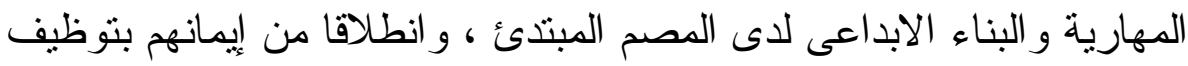

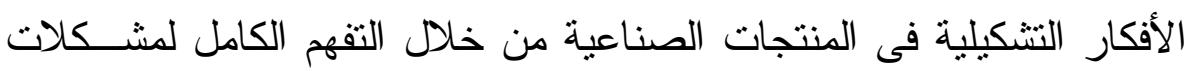

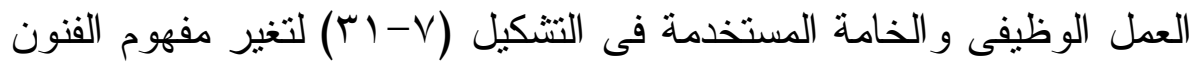

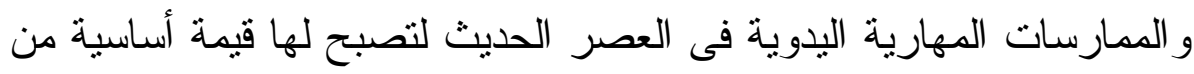

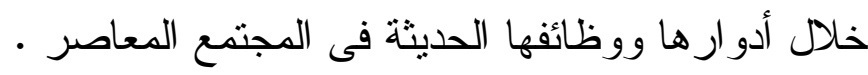

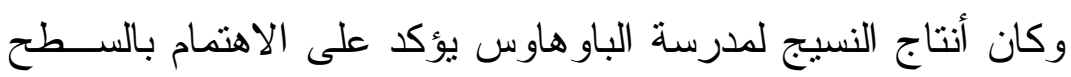

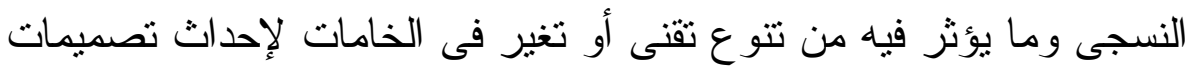

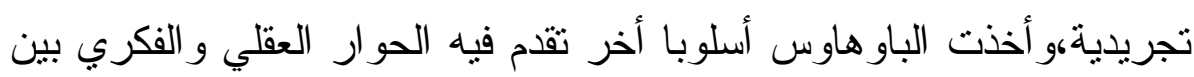

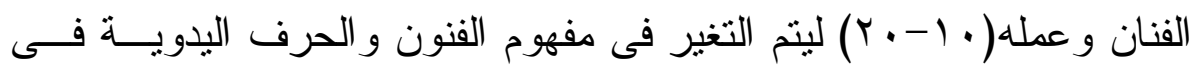

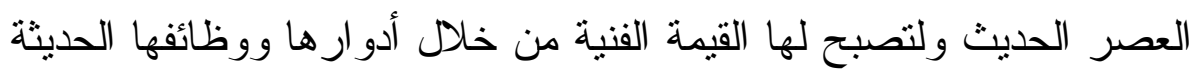

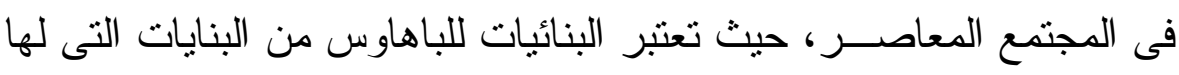




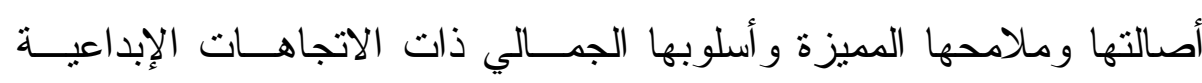

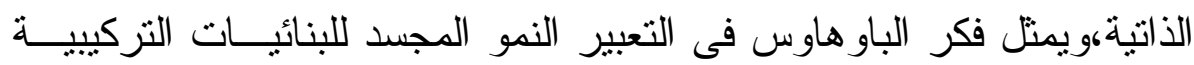

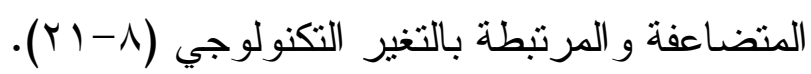
وتسعى الباو هاوس فى عدم فرض بالغير رأى أى أو فكرة بل أن أن أهم شئ بميز

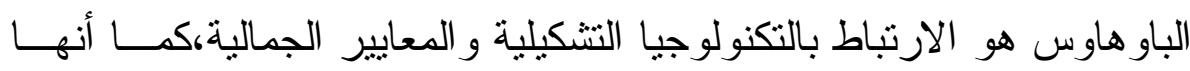

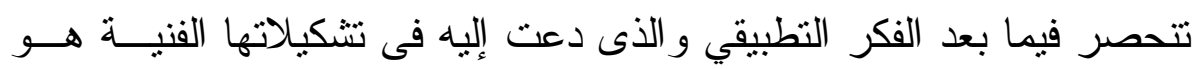

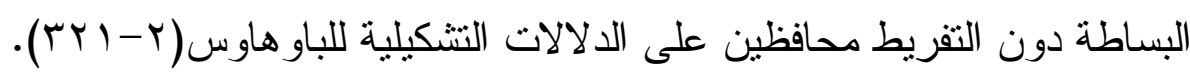

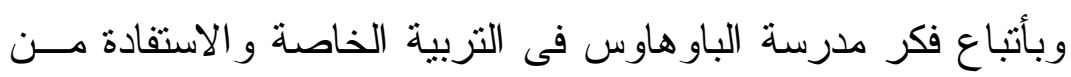

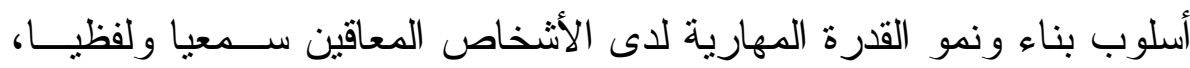

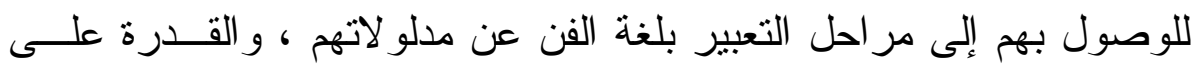

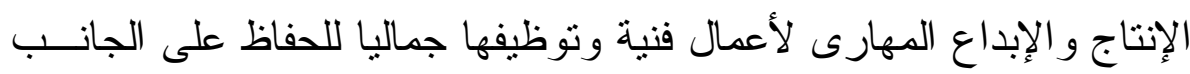

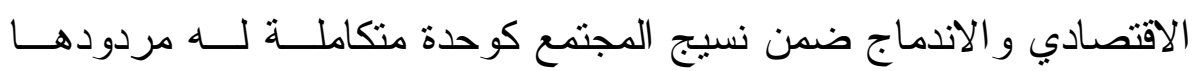

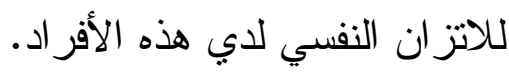
المحور الثاني: التجريب بالتر اكيب النسجية البسيطة و الزخرفية كمدخل للإبداع الفنى:

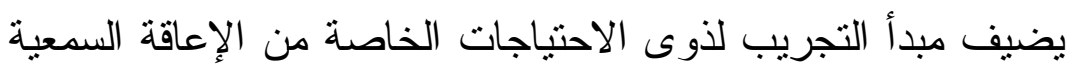

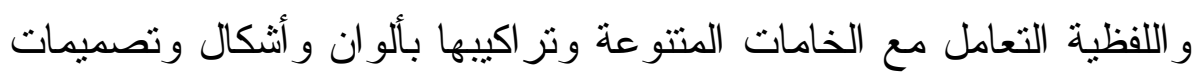

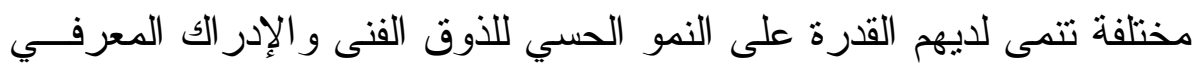

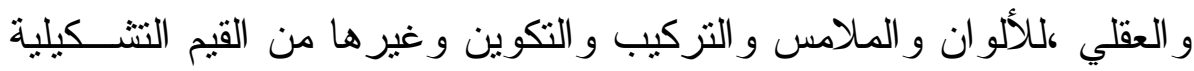

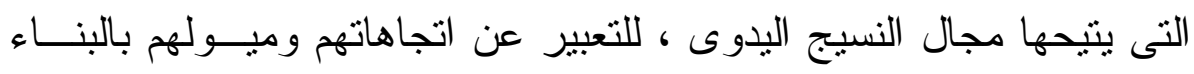

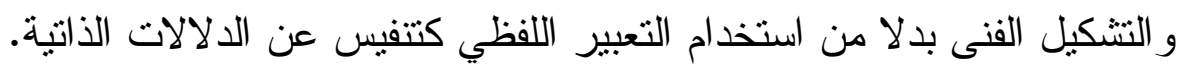

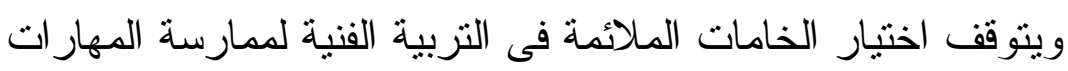

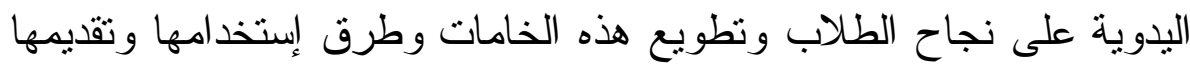

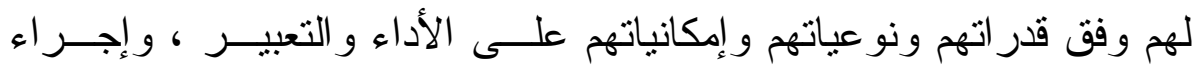




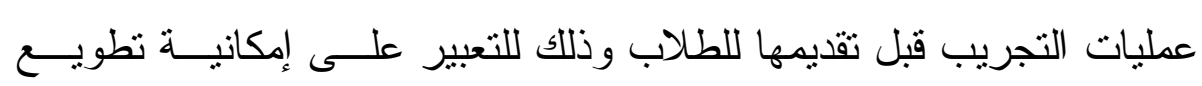

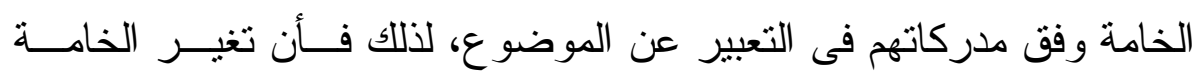

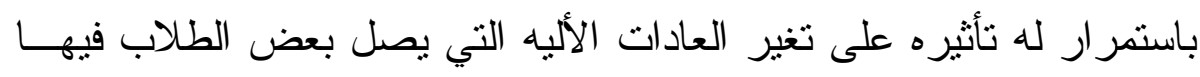
إلى درجة الثبوت نتيجة نكر ار الخامة و الأدو ات على وتيرة و احدة.

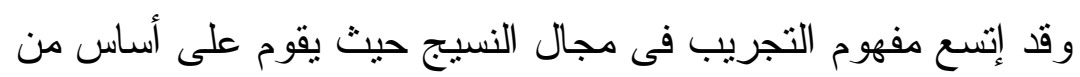

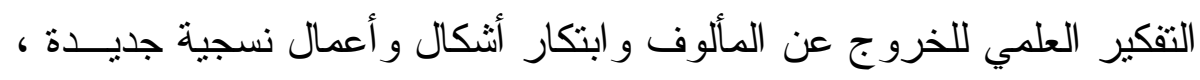
فغاية التجريب هى السعي و التدريب على ممارسة الفكر الابتكارى، وتعتبــر

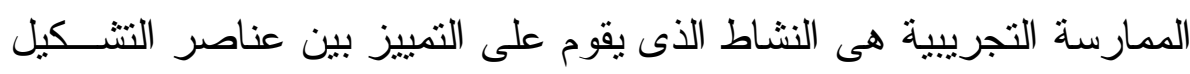

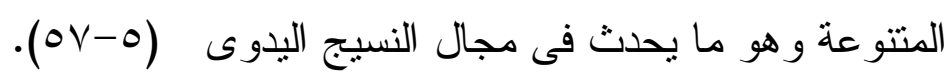
و التجريب أسلوب فى الأداة الفني كما أنه نشاط أبداعي قد يكون في في

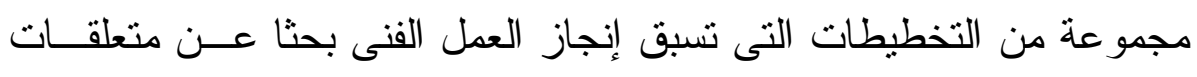

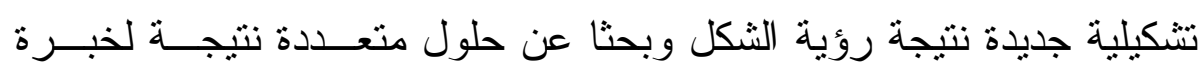

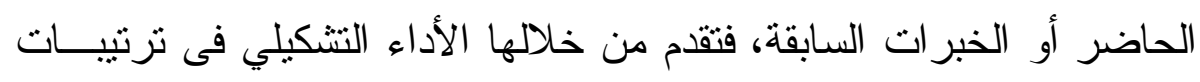
مستحدثة، ليصبح هذا الإنتاج هو عمل إيتكارى ومحصلة للتجريب، وترتبط

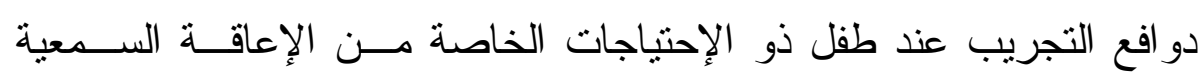

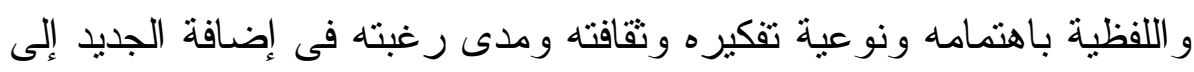

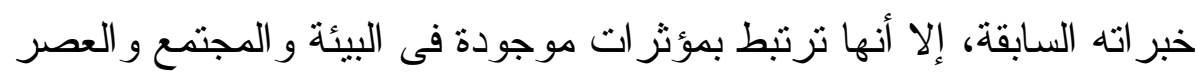
الذى يعيشه، و أيضا دو افع مرتبطة بالتطور ات العملية و الفكرية و السياســية

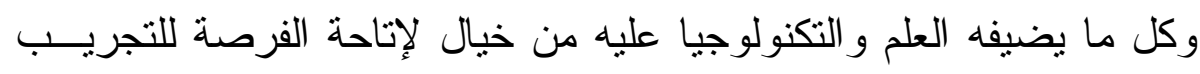
المقنن و إضافة الجديد.

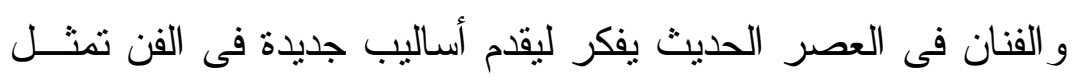

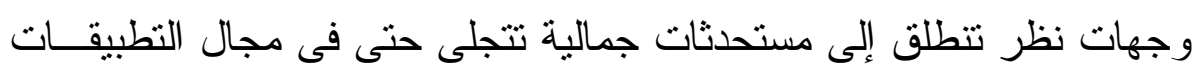
العملية، ولا يقل عنه في هذا المجال ذوى الاحتياجات الخاصة من الإعاقـــة السمعية و اللفظية بعد توجيههم وتدريبهم لتصبح لهم نفس الرؤى التى تتخلل

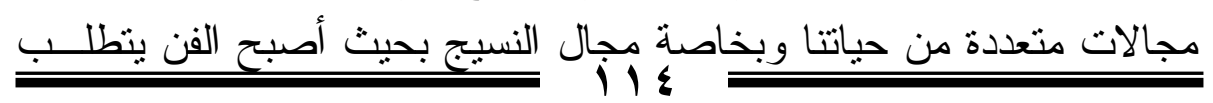




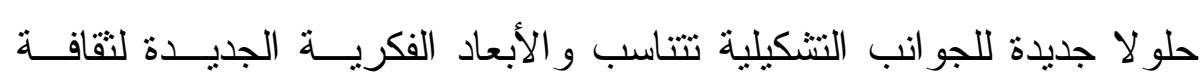
العصر ، ويعتقد أن أسلوب التجريب يصاحب كل عقلية مفكرة إبتكارية تبحث

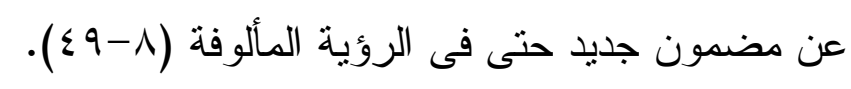

\section{• المداخل التجريبية للمهار ات اليدوية النسجية :}

من خلال التعرف على عينة من الصم البكم يتم تقديم مقتـرح مــن

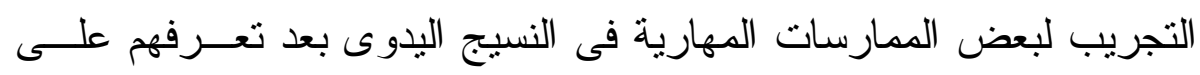

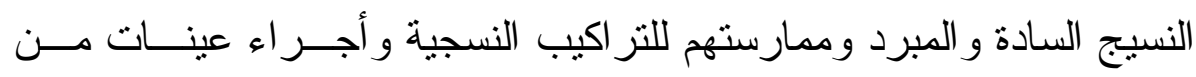

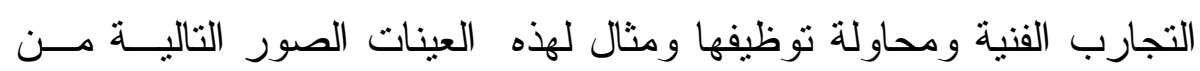
تجارب الأعمال النسجية المقترحة.

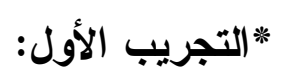

مداخل تجريبية للممارسات المهارية بخامات مختلفة واختيار ات لونية منفذه بالتركيب النسجى السادة، ومحاولة توظيفها

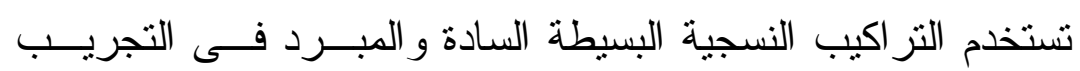

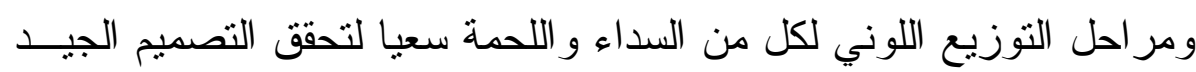

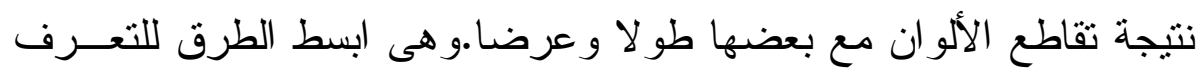

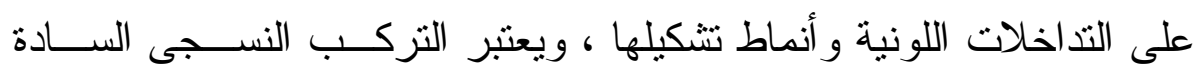
و التركيب المبردى من التز اكيب النسجية البسيطة التىى يمكن تشغيلها بــدويا

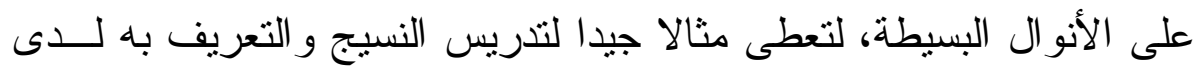

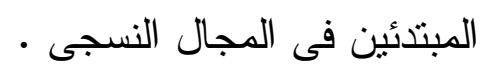

و النسيج السادة Plain Weave هو أبسط أنو اع التر اكيب النسجية ،

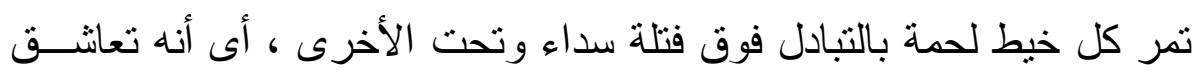

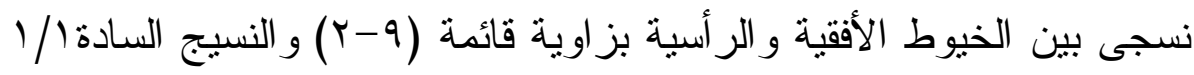

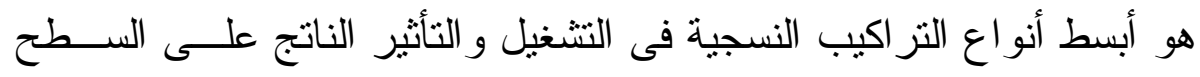




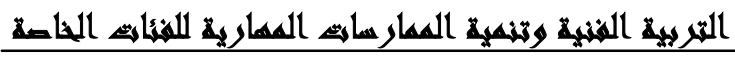

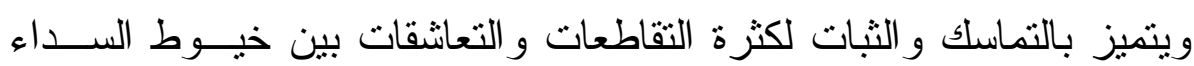
و اللحمة ليصبح المسطح المنسوج أكثر أندماجا.

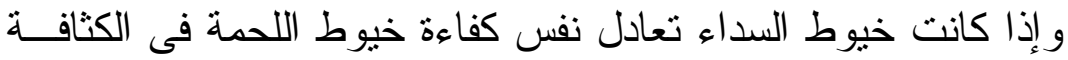

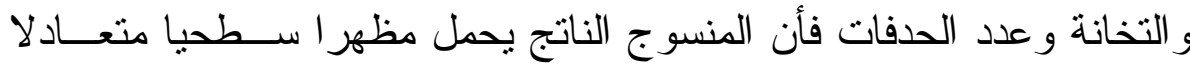

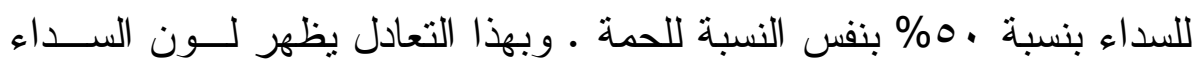

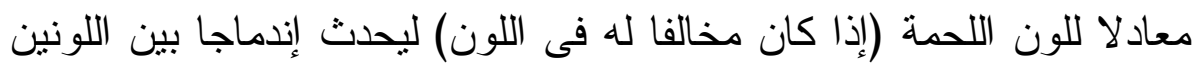

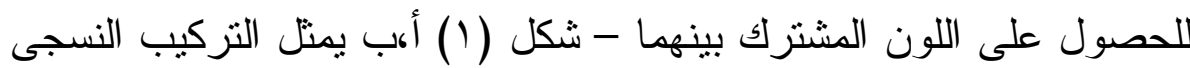

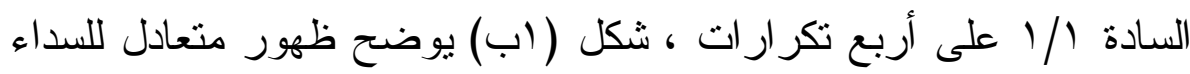

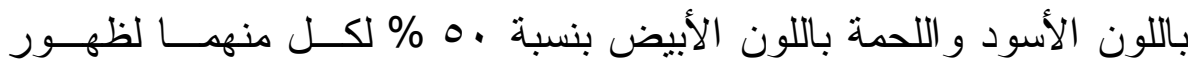
السطح النسجى باللون الثالث المشترك بين اللونين.

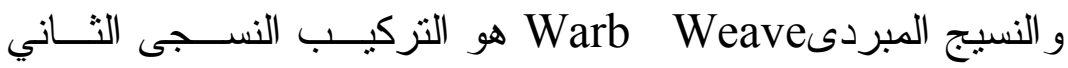

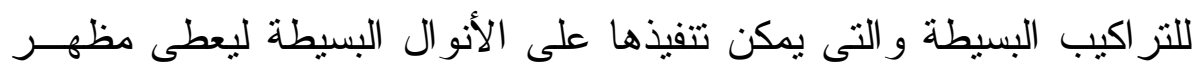

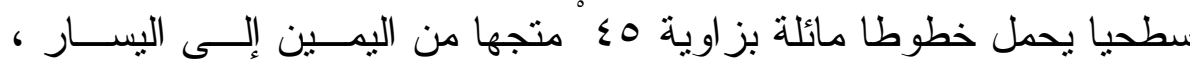

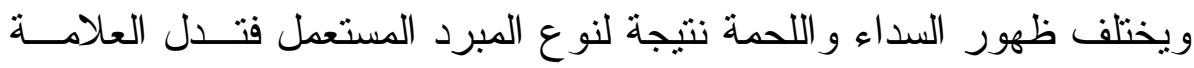

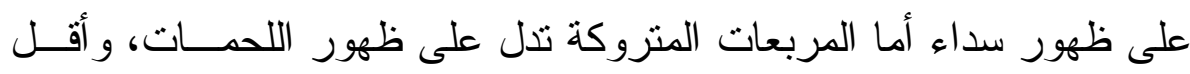

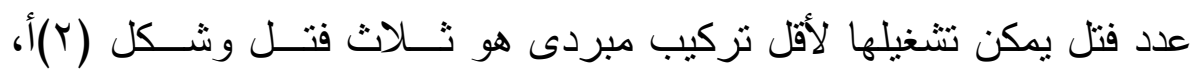

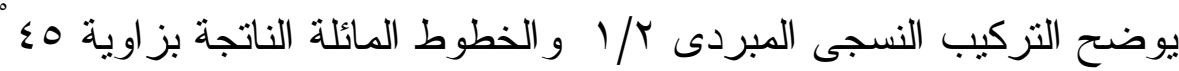

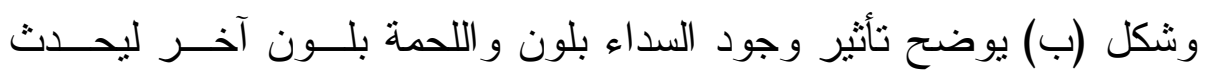

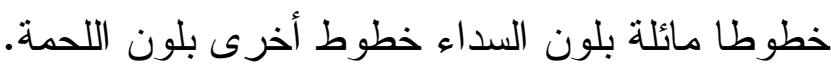

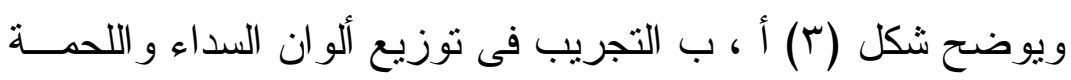

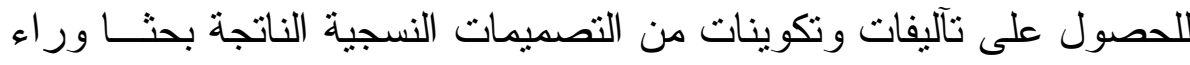

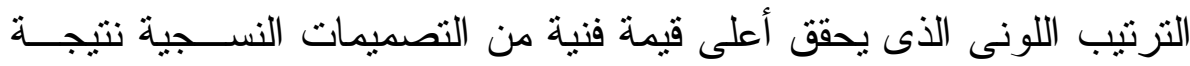

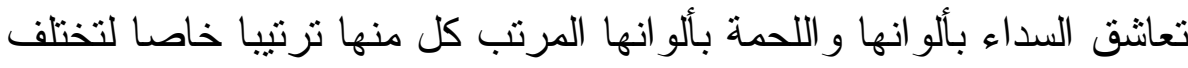

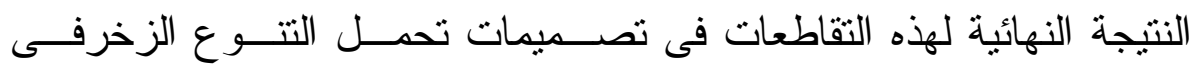


و التجريب باللون للحصول على بعض التصميمات الزخرفية للنسيج الســادة

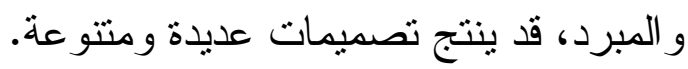

$$
\text { * التجريب الثاني: }
$$

مداخل تجريبية لممارسات نسجية بتقتيات زخرفية متنوعة مــع النســيج

السادة ومحاولة لتوظيفها.

التقنيات الزخرفية النسجية هى مشتقة من التركيب النسجى الســادة

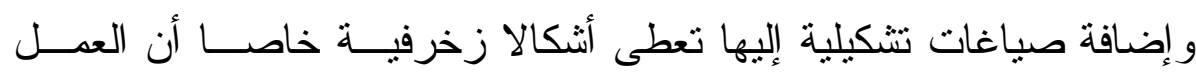
يتصف بالفردية و المهارة البدوية،وهى تقنيات متعارف عليها فى مجال العمل

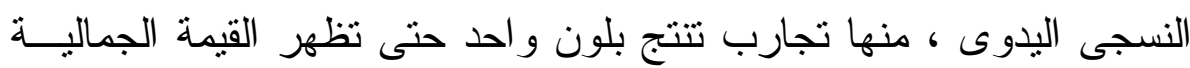

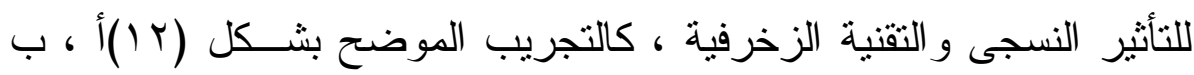

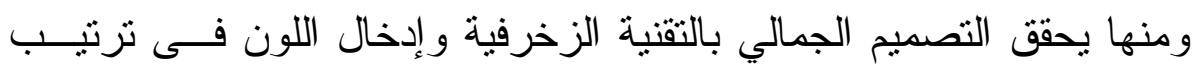

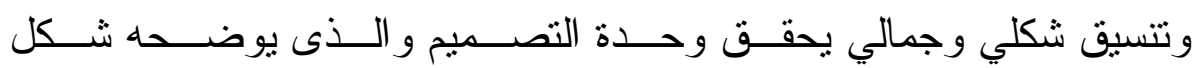
ب أ (l (1)

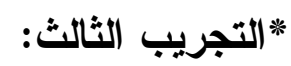

مداخل تجريبية لأعمال نسجية متتوعة الأثكال تحمل تصميمات تعبيريــة وجمالية:

وحتى لا يتجرد الفن من قيمه الجمالية وينحصر فى الجانب الوظيفى

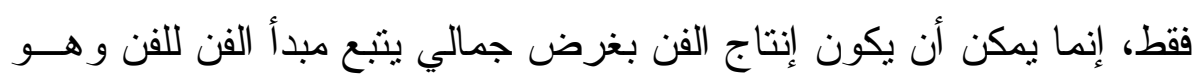

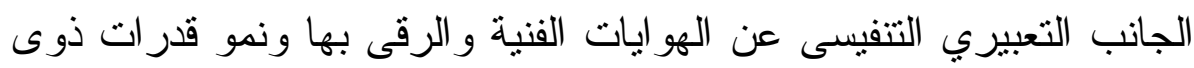
الاحتياجات الخاصة فى التعبير المهار ات معا فى صياغة نتكيلية منفردة تتبع بصمة الفنان وفر ادة إنتاجه الفني المعبر عن فكرته ـ ـ ومثال عنها الأشـــال

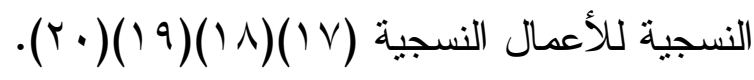


المحور الثالث:

ربط القيمة الإبداعية بالجانب الوظيفى للعمل النسجى :

من المحور الأول لتوظيف الأعمال النسجية عند الباو هاوس و المحور

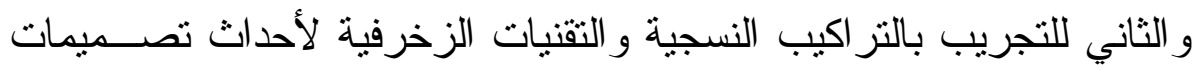
فنية و التى تطرح كمداخل للتجريب، لأهمية العمل النسجى يمكن توظيف هذه

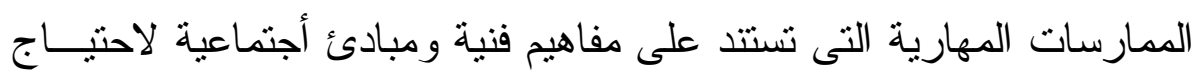

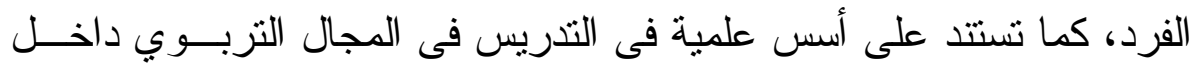
التزبية الفنية لر عاية ذوى الاحتياجات الخاصة من الإعاقة السمعية و اللفظية.

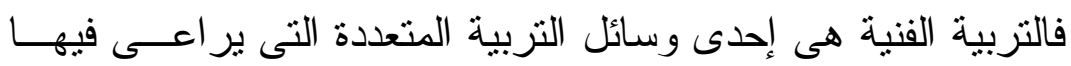

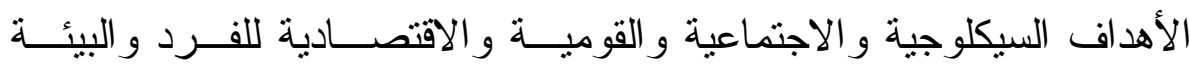

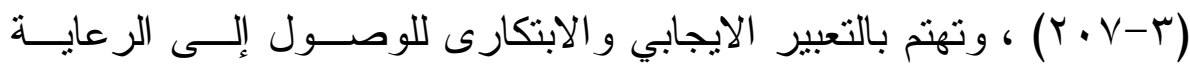

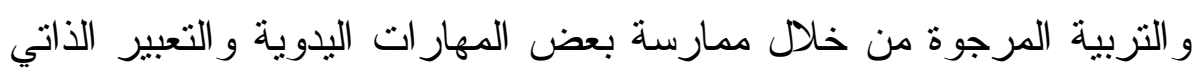

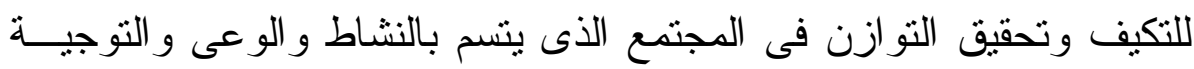

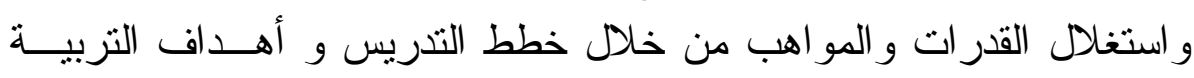
الفنية. لذا فمن هذا المنطلق كان الاستتاد على الجانب المهارى و المعرفي لفن

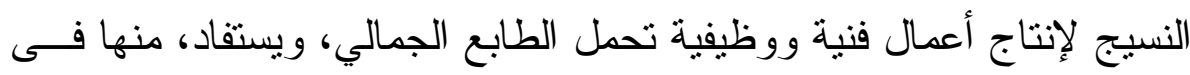
المجال التعليمي للفنون وذلك بأجر اء بعض المحاو لات التجرييية فى التربية الخاصة فى مجال الفن للتو اصل إلى أسلوب تعليمي تدريبي تجريبي نـاجح بالاستفادة من التر اكيب النسجية البسيطة فى أعمال فنية وظيفية تكون بمثابة

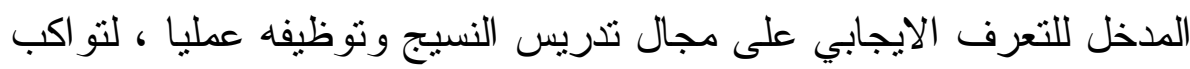
النسجيات اليدوية التحديات و التطور ات للمتطلبات الاجتماعية. ومن ممارسات التجريب الأول يمكن توظيف التدريبات النسجية بمهارات

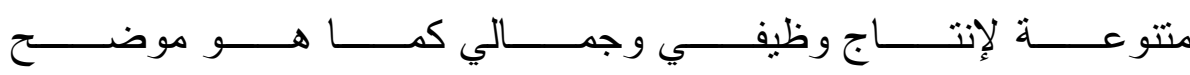

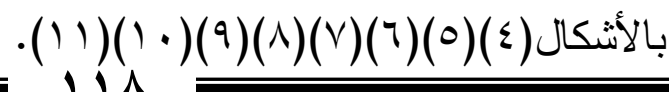


ومن ممارسات التجريب الثاني يمكن توظيف التذريبات النسجية بمهار ات منتو عة لإنتاج وظيفي وجمالي كما هو موضتح بالأشكال(ع ())أبب(0 1 )( 1 ( ). الاتتائج و التوصيات:

من نتائج هذه الدر اسة التجريبية وضع مداخل لتدريس احد مجــالات

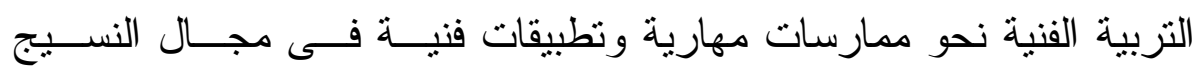

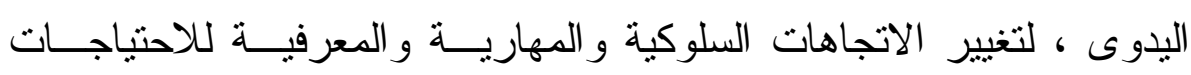
الخاصة من القدر ات السمعية و اللغوية.

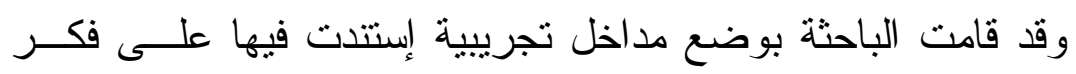

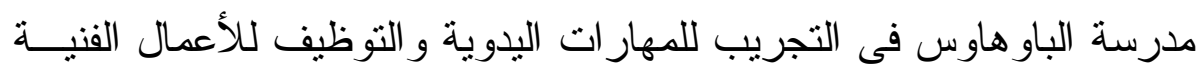

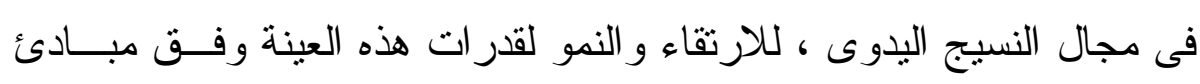
التطوير نحو ممارسات أفضل فى التزبية الخاصة.

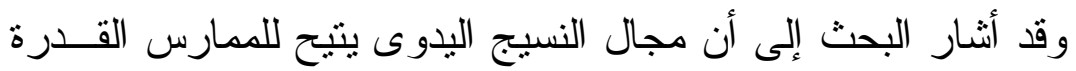

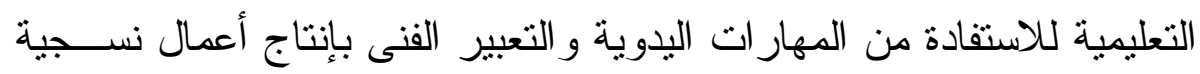
مبتكرة لها مردود نزبوي ونفسي على عينة الاحتياجات السمعية و اللفظية .

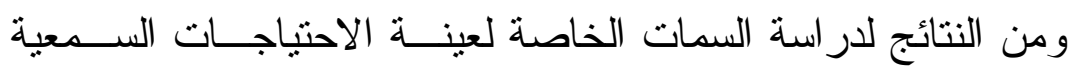

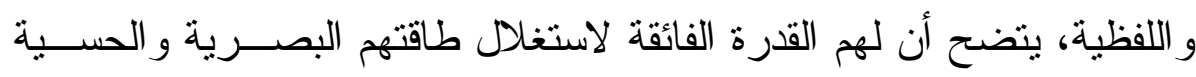

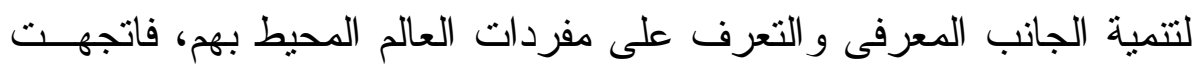

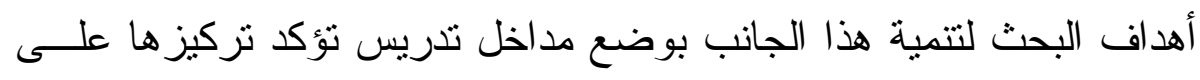
الجانب البصري و الحسي لتعليم المهار ات اليدوية وتتمية القدرة على الإنتاج

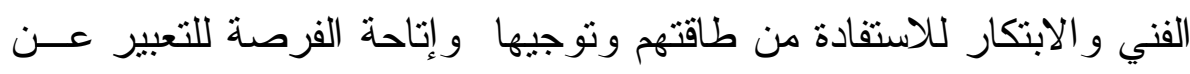

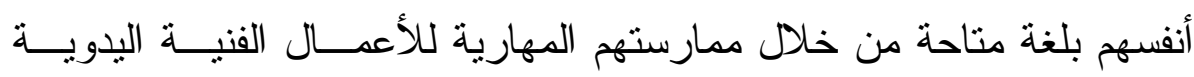

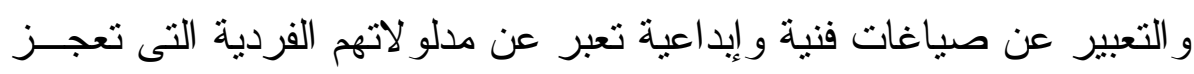
القدر ات السمعية و اللفظية الإشادة بها. 


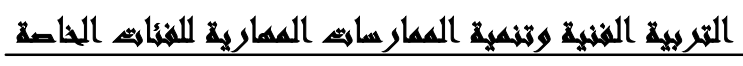

كما يتضح بر اعة هذه العينة لاستخدام قدر اتهم البصرية و الحسية فى الإئ

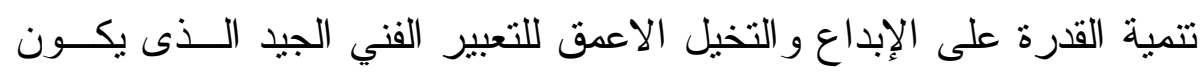

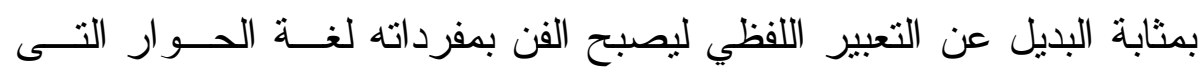

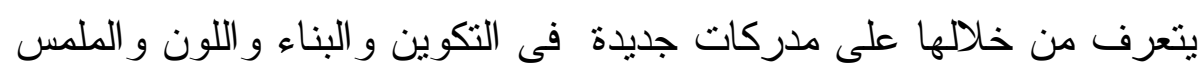

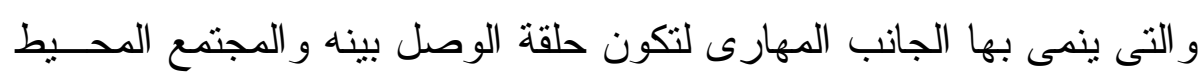

ويوصى البحث باستخدام الممارسات المهارية و التجارب البحثية فى في

التربية الفنية ضمن ممارسات التربية الخاصة لذوى الاحتياجــات الســمعية و البصرية للتعبير عن أنفسهم بوسائل جديدة وبديلة لمفردات اللغـــة اللفظيـــة حتى يتحقق الاتزان النفسي بين الفرد وذاته وبين الفرد و المجتمع • 


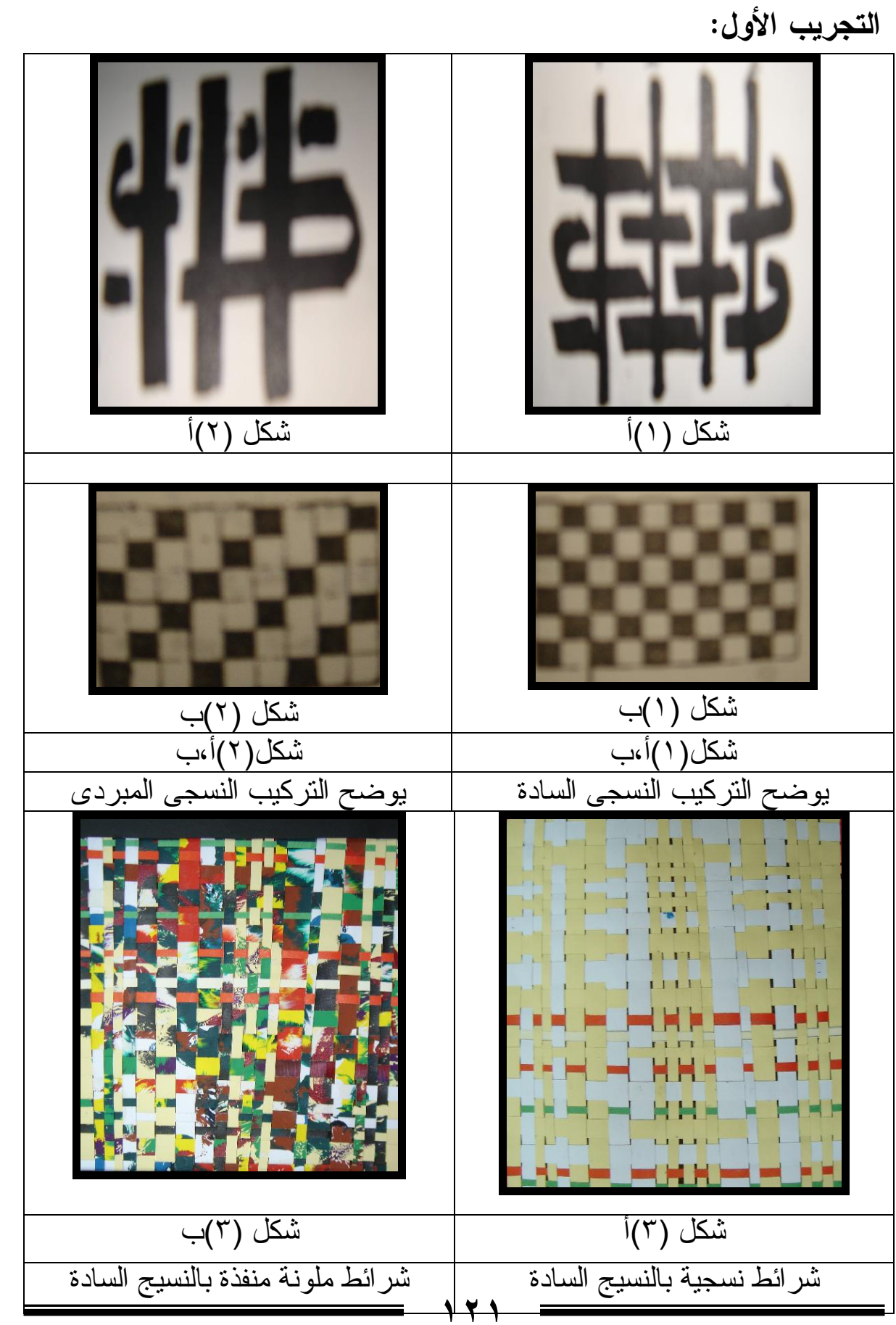




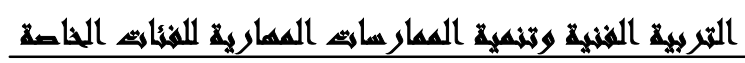

$$
\text { أعمال وظيفية للتجريب الأول }
$$

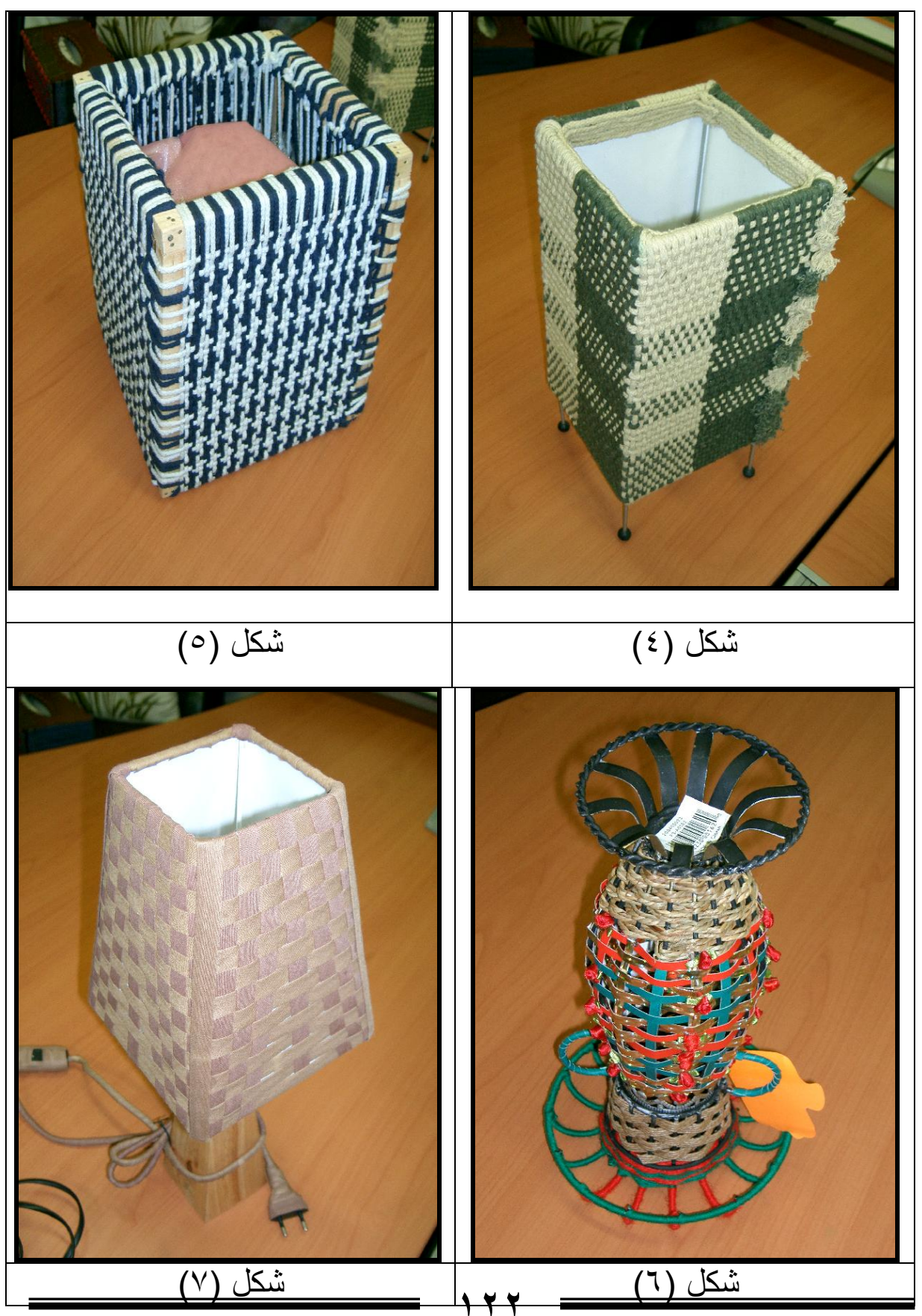




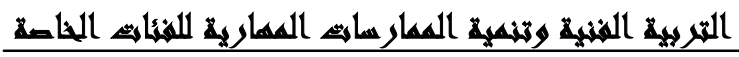

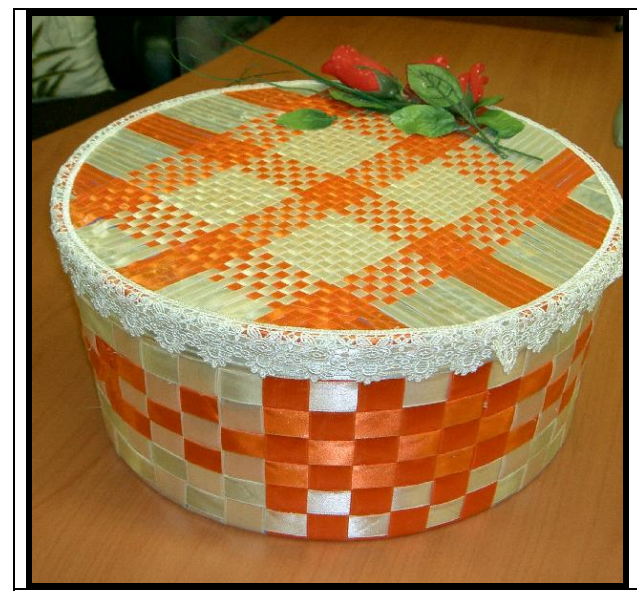

شكل (9)

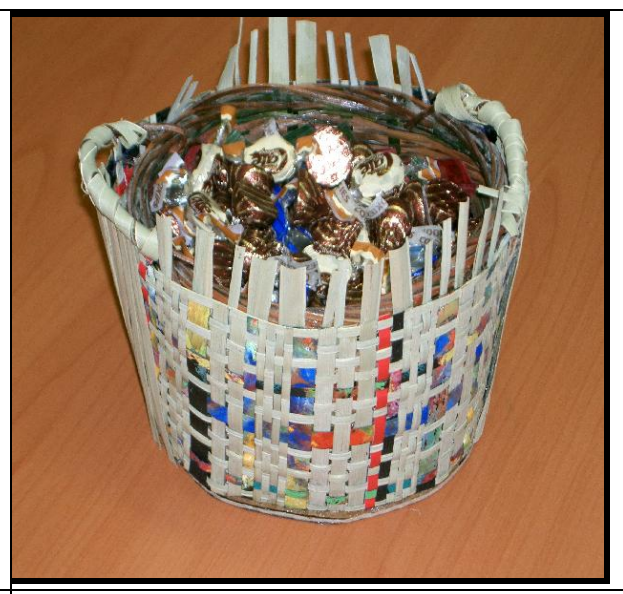

شكل (^)

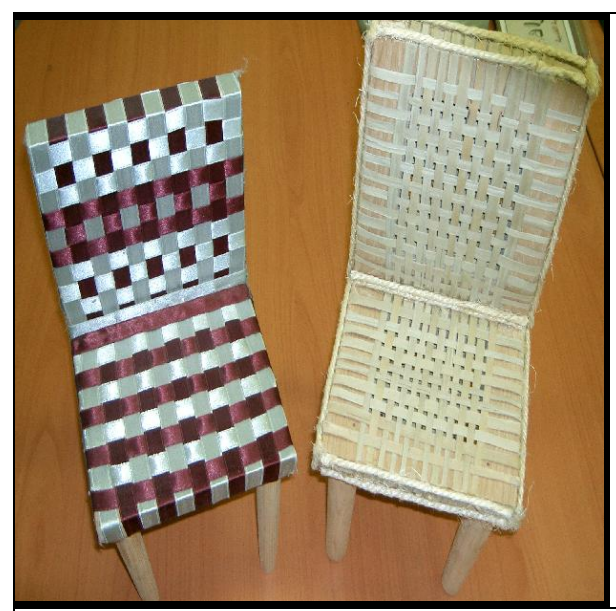

شكل (I')

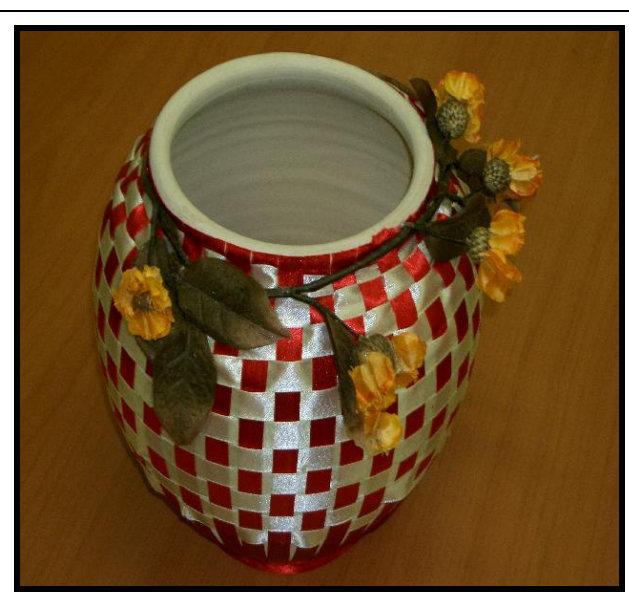

شكل (.) 


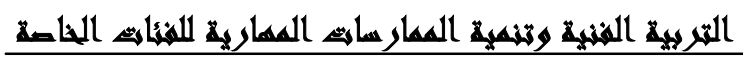
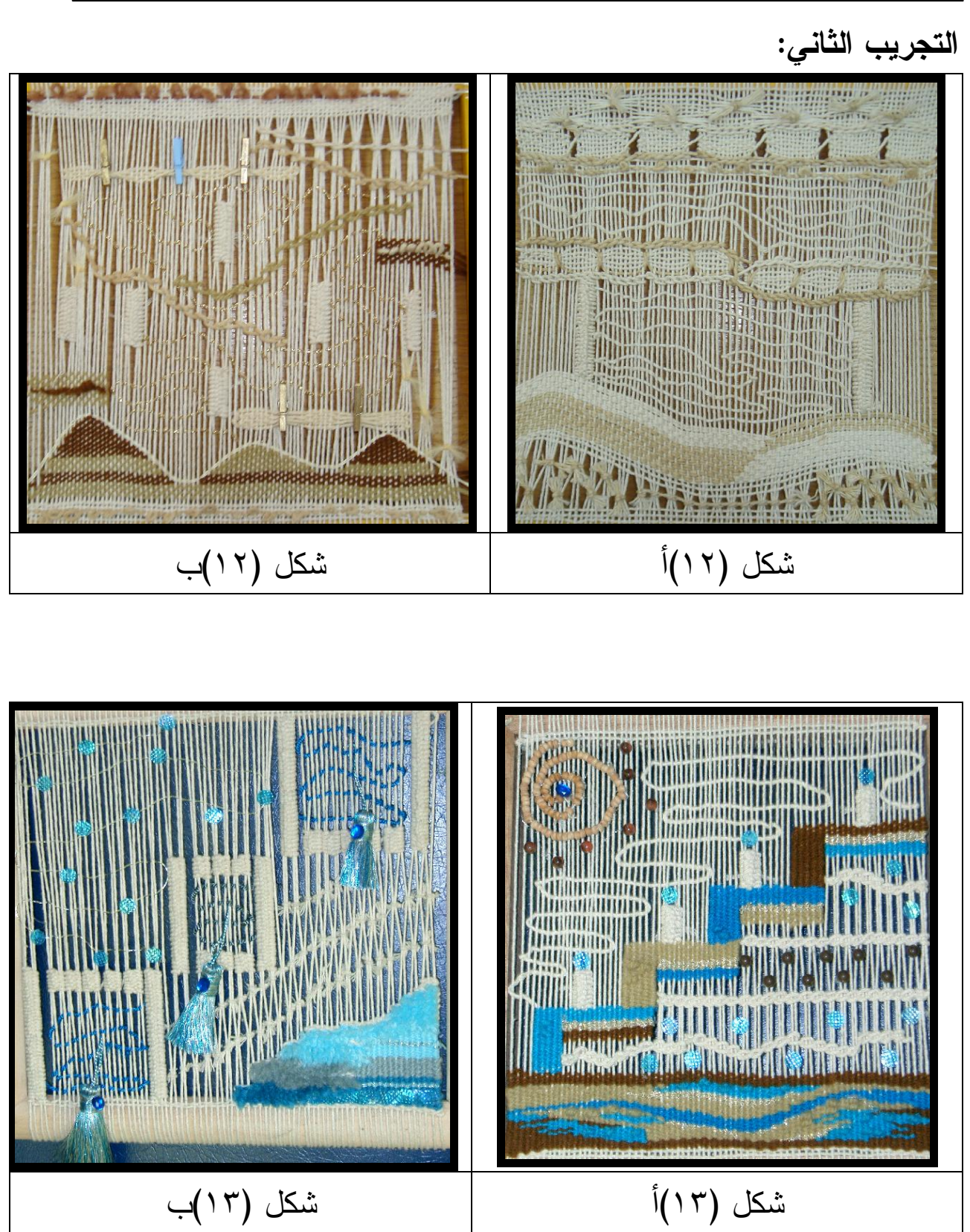

شكل (r))

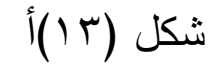




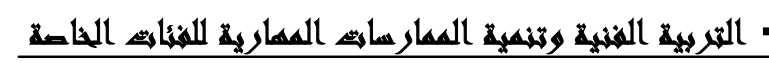
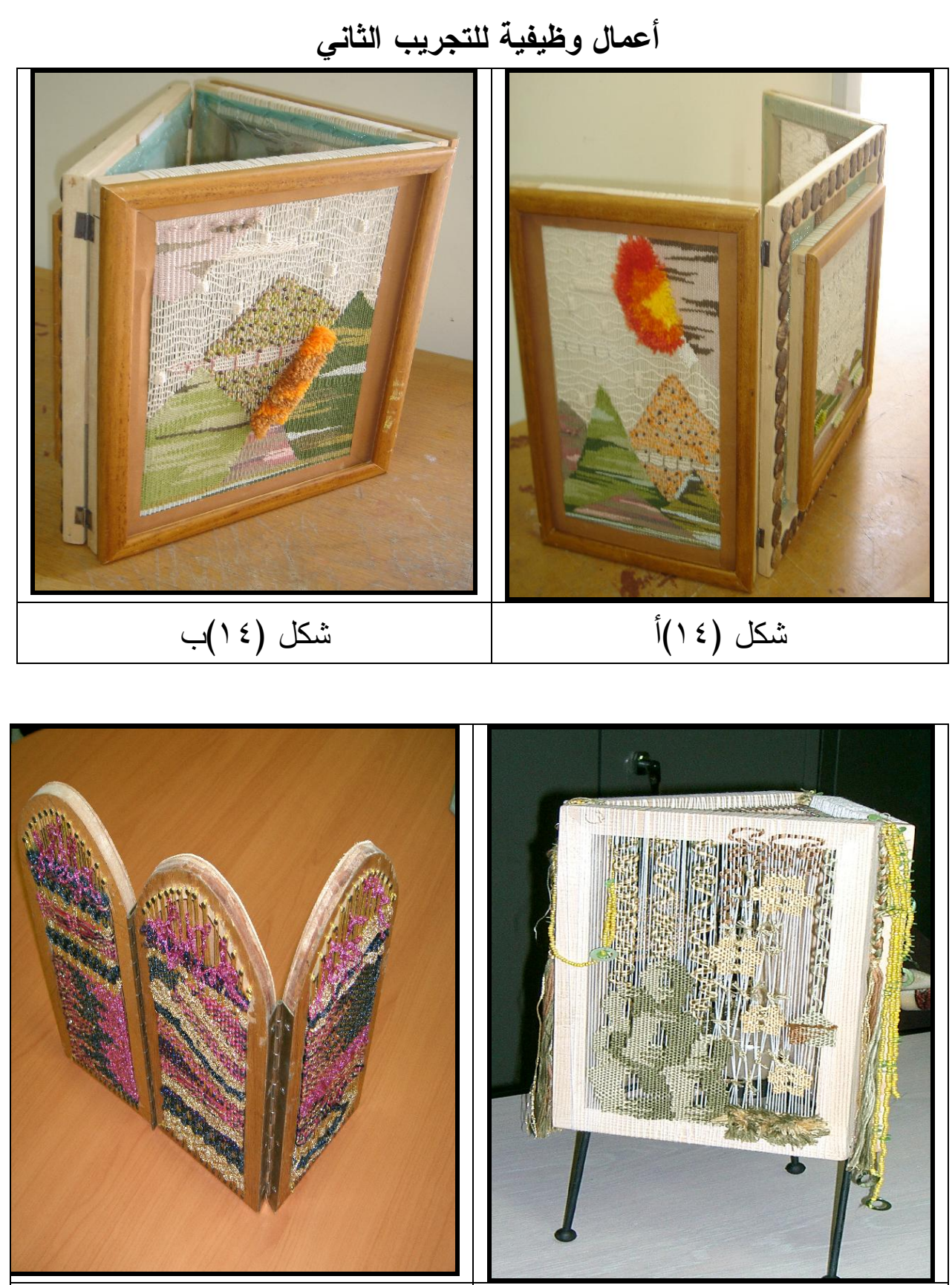

شكل (17)

شكل (10) 


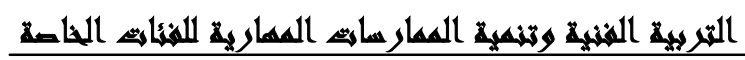
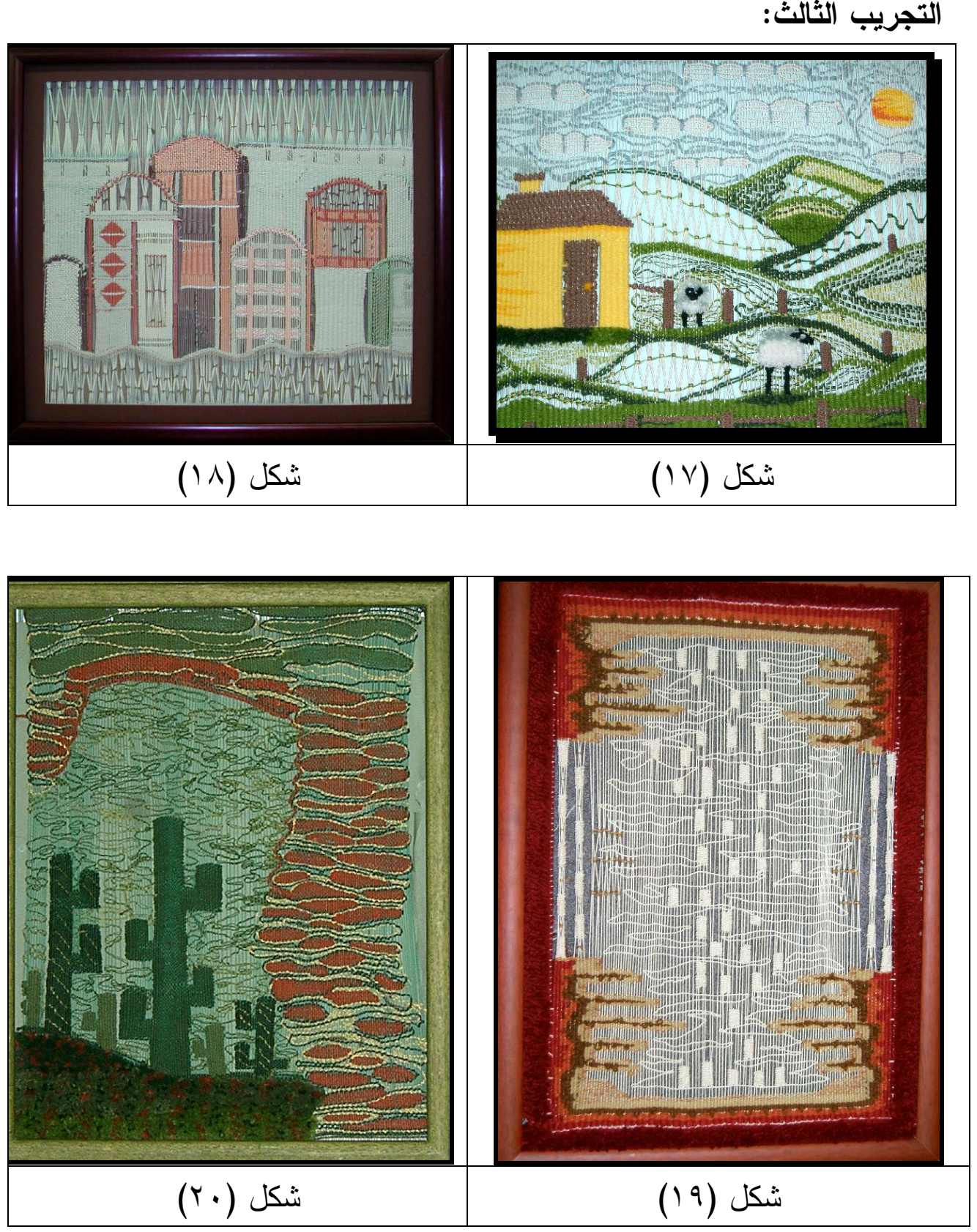


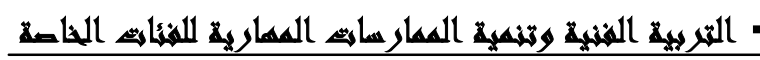

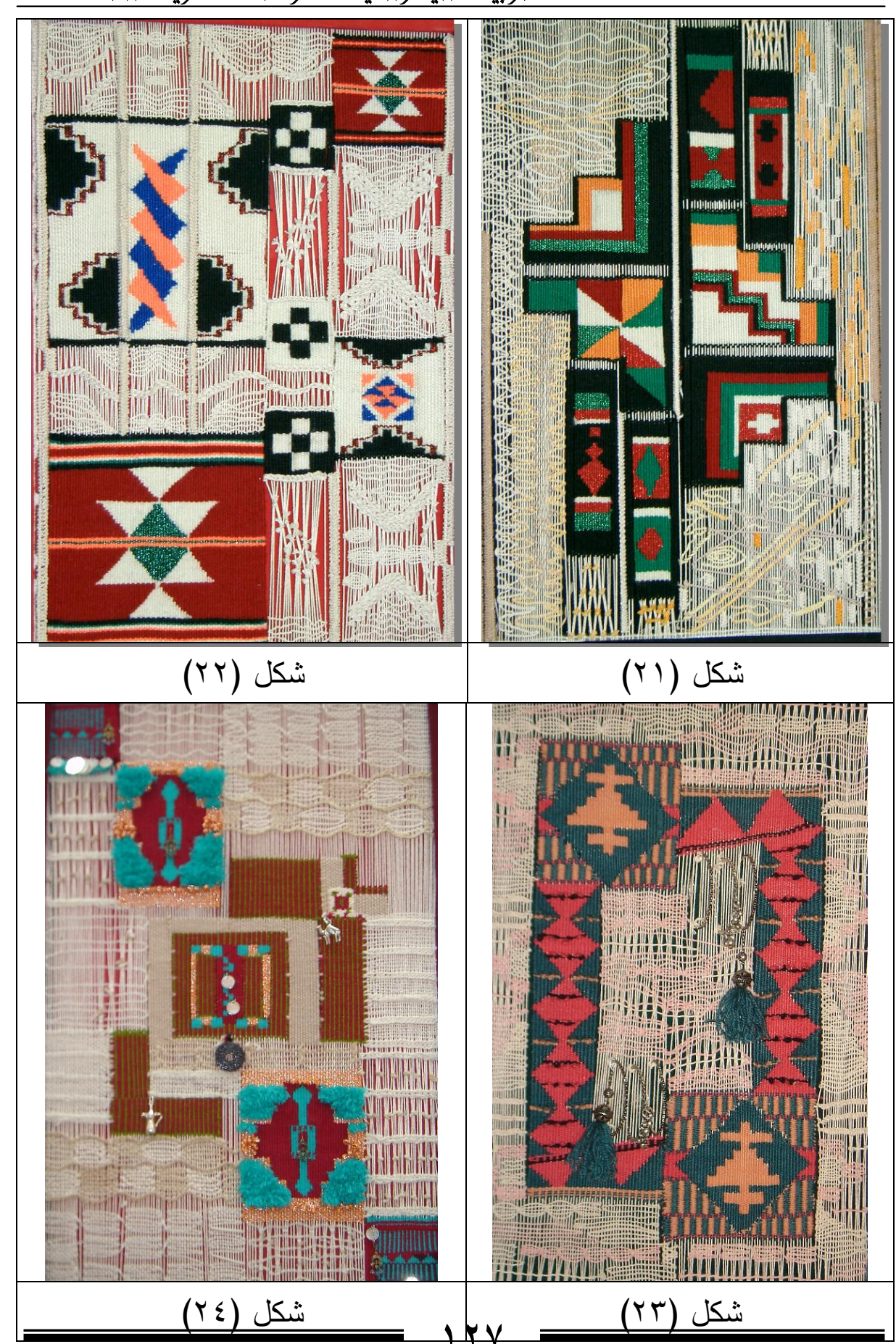




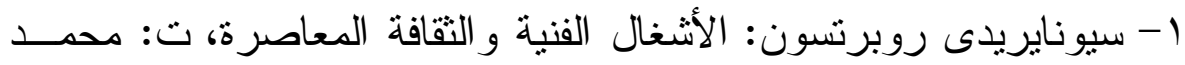
خليفة بركات، مؤسسة سجل العرب،القاهرة. ץ- علاء سليمان: إستخدام الكمبيوتر فى إبتكار أثنكال مجسمة مستقبدا مـن تطبيقات مدرسة الباو هاوس، رسالة دكتور اه، غير منشـــورة،كليــة التربيــة الفنية،جامعة حلو ان، 199 أب 19

r- محمود البسيونى: طرق تعلم الفنون، دار المعارف، القاهرة، 1911 . ع - محمود عبد العاطى: توظيف البعد الثالث الحقيقي فى التصوير الحديث، رسالة دكتور اه،غير منشورة، كلية التربية الفنية، جامعة حلو ان، I9NV 0- نعمات جمال الدين: تصميم نول يدوى لإثر اء الممارسة الإبتكارية فـى مجال التر اكيب النسجية المجسمة لطلاب التربية الفنية، رسالة دكتور اه، غير منشورة،كلية التربية الفنية، جامعة حلو ان، 191 ا ـ ـ 7- نعمت إسماعيل علام: فنون الغرب فى العصر الحديث ، دار المعارف،

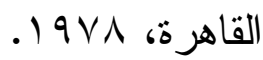

V- يوهانس إيتن: الدورة الأساسية فى الباوهاوس، ت: وجدان ماهر ، مجلة

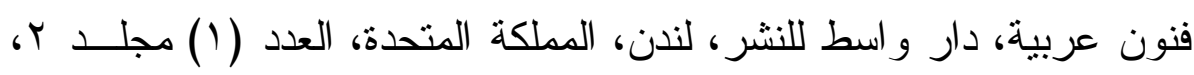
$.191 \mathrm{r}$

(8) Chales New Man:" What is Post Modernism " Academy Edition, London, 1986.

(9) Grosicki. Z- Watsons; Textile Design and Color Newnes, London Butter Worths, 1980.

(10) Irene Walle: Textile Sculptures, Astudio Vista Book, published by cassal and collier Macmillan. Lta, London 1977. 